\title{
As Jazidas de Talco no Contexto da História Metamórfica dos Metadolomitos do Grupo Itaiacoca, PR
}

\author{
Gergely Andres Julio Szabó' (gajszabo@usp.br), Fábio Ramos Dias de Andrade', Gilson Burigo Guimarães², \\ Flávio Machado de Souza Carvalho', Fernando Assumpção Moya ${ }^{3}$ \\ 'Departamento de Mineralogia e Geotectônica - Instituto de Geociências - USP \\ R. do Lago 562, CEP 05508-080, São Paulo, SP, BRA \\ ${ }^{2}$ Universidade Estadual de Ponta Grossa, Ponta Grossa, PR, BRA \\ ${ }^{3}$ Cimentos Votoran S.A., Curitiba, PR, BRA
}

Recebido em 19 de setembro de 2005; aceito em 16 de janeiro de 2006

Palavras-chave: metadolomito, talco, talcificação, Grupo Itaiacoca.

\section{RESUMO}

Quatro formas de ocorrência do talco foram reconhecidas nos metadolomitos proterozóicos do Grupo Itaiacoca, PR: a) talco xisto em zonas de cisalhamento transcorrentes; b) fraturas e planos de acamamento incipientemente talcificados; c) bolsões irregulares de talco maciço fino, pulverulento; d) talco retrometamórfico associado a olivina, diopsídio, tremolita, calcita e quartzo na zona de contato com granitos vizinhos. Dentre estes, apenas os tipos (a) e (c) formam jazidas de importância econômica. O Grupo Itaiacoca passou por quatro episódios metamórficos: 1) metamorfismo regional facies xisto-verde durante o Ciclo Brasiliano no Neoproterozóico; 2) metamorfismo termal ao longo do contato com o Complexo Granítico Cunhaporanga; 3) hidrotermalismo relacionado a zonas de cisalhamento transcorrentes, que levou à formação de grandes volumes de talco xisto e bolsões de talco maciço; 4) metamorfismo termal de pequena abrangência espacial relacionado a diques de diabásio mesozóicos. As principais jazidas de talco encontram-se alinhadas segundo as ramificações da zona de cisalhamento transcorrente Itapirapuã, que marca o contato entre o Grupo Itaiacoca e o Complexo Granítico Três Córregos. $\mathrm{O}$ aumento da permeabilidade devido ao cisalhamento permitiu a percolação de soluções aquosas ricas em sílica, que reagiram com o metadolomito para formar as jazidas de talco. Quantidades subordinadas de talco ocorrem ao longo de planos de estratificação e fraturas. Os bolsões de talco maciço (tipo c) substituíram o metadolomito de modo estático e provavelmente formaram-se a temperaturas mais baixas pela atividade de fluidos hidrotermais introduzidos através de uma rede de microfraturas.

Keywords: metadolomite, talc, talcification, Itaiacoca Group.

\section{ABSTRACT}

Four main types of talc occurrences have been recognized in the Proterozoic metadolomites of the Itaiacoca Group, Paraná State, southern Brazil: a) talc schists along transcurrent shear zones; b) incipient talc formation along fractures and bedding planes; c) irregular pockets of fine-grained, massive talc; d) retrometamorphic talc associated with lenses of olivine, diopside, tremolite, calcite and quartz in the contact zone with the neighbouring granites. Of these, only types (a) and (c) form ore deposits. The Itaiacoca Group underwent four metamorphic episodes: 1) greenschist facies regional metamorphism during the Neoproterozoic Brasiliano orogeny; 2) thermal metamorphism along the contact with the Neoproterozoic Cunhaporanga granite batholith; 3) hydrothermalism related to transcurrent shear zones, that formed large volumes of talc schists and irregular pockets of fine-grained massive talc; 4) small-scale thermal metamorphism related to Mesozoic diabase dikes. The Itapirapuã transcurrent shear zone marks the contact between the Itaiacoca Group and the Proterozoic Três Córregos granite batholith, and the main talc deposits are aligned along its branches. Enhanced permeability due to shearing provided channels for percolation of the silica-rich aqueous solutions that reacted with the metadolomite to form the talc deposits. Minor amounts of talc occur along fractures and sedimentary layering. The massive pockets of talc (type c) that replaced the metadolomite probably formed statically at lower temperatures by the activity of hydrothermal fluids introduced through a network of microfractures. 


\section{INTRODUÇÃO}

Vários modelos foram propostos para a gênese das jazidas de talco em metadolomitos do Grupo Itaiacoca, Estado do Paraná, que respondem por $23 \%$ da produção nacional de talco (DNPM, 2004). Barbosa (1943) e Sobanski et al. (1984) atribuíram a talcificação ao metamorfismo de contato dos diques básicos do Arco de Ponta Grossa. Lima (1992, 1993a, 1993b, 1997) e Lima e Dardenne (1987) reconheceram uma primeira geração de talco associada ao metamorfismo regional e a cavalgamentos (650 - $750 \mathrm{Ma})$, e uma segunda geração relacionada à percolação de fluidos hidrotermais por falhas transcorrentes de direção nordeste $(550 \mathrm{Ma})$, fluidos estes de origem superficial cuja circulação teria sido provocada pelo aquecimento devido à colocação dos granitos Três Córregos e Cunhaporanga. O relatório DNPMMINEROPAR (1999) classificou estes depósitos em:

a. ligados ao metamorfismo, pela circulação de água $\left(350-450^{\circ} \mathrm{C}\right.$ ) em zonas de cisalhamento associadas a falhas de cavalgamento e regiões fraturadas subverticais, planoaxiais a dobras abertas;

b. ligados à alteração superficial, retrabalhamento e concentração do talco metamórfico.

O presente trabalho apresenta um modelo da gênese das jazidas de talco do Grupo Itaiacoca, com base na história metamórfica das rochas dolomíticas, a partir de observações de campo e petrográficas, análises de difração de raios X, microssonda eletrônica, microscopia eletrônica de varredura e análises químicas de rocha total. Resultados parciais foram apresentados por Szabó et al. (2004).

\section{MÉTODOS ANALÍTICOS}

As análises petrográficas e mineralógicas foram realizadas em amostras de minério de talco coletadas in situ, minério bruto extraído e estocado "tal-qual", minério prébeneficiado por separação granulométrica em peneiras em rampa e catação manual, minério beneficiado (cominuído, peneirado, seco em forno), metadolomitos, mármores dolomíticos, além de rochas associadas tais como filitos, rochas metabásicas, granitos e diabásio. Foram preparadas seções delgadas convencionais e seções não recobertas por lamínula, para realização de teste de coloração diferencial de carbonatos por azul de lizarina (Hutchison, 1974). Análises por difratometria de raios X (DRX) em amostras de pó foram efetuadas em difratômetro Siemens D5000 com tubo de cobre $\left(\mathrm{Cu} \mathrm{K}_{\alpha}\right), 40 \mathrm{kV}, 40 \mathrm{~mA}$, com varredura em passos de $0,05 \% \mathrm{~s} \mathrm{e}$

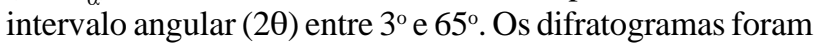
interpretados utilizando o banco de dados JCPDS-ICDD e o programa Diffrac AT PLUS. Amostras contendo asbesto foram preparadas em caixa de luvas, com o uso adicional de máscaras de proteção específicas. As análises químicas minerais por microssonda eletrônica foram obtidas com equipamento JEOL JXA SuperProbe 8600 com 5 espectrômetros, utilizando sistema de análise automatizada WDS 4.1 Termo-Noran e EDS acoplado. As condições de operação foram $15 \mathrm{kV}, 20,10 \pm 0,10 \mathrm{nA}$, diâmetro do feixe $5 \mu \mathrm{me} 10 \mu \mathrm{m}$, com correções quantitativas através do programa PRZ Termo-Noran. O erro analítico foi estimado em $\pm 3 \%$ para os elementos analisados. As imagens de elétrons secundários e retroespalhados e análises químicas qualitativas (EDS) por microscopia eletrônica de varredura (MEV) foram obtidas em equipamentos Philips e Leo 440I, corrente 20kV, usando recobrimento com carbono.

Análises químicas de rocha total foram executadas por espectrometria de emissão óptica com plasma induzido acoplado (ICP-AES ARL-3410) e de fluorescência de raios X (Philips Analytical PW 2400) em pastilhas fundidas e prensadas para os elementos maiores e menores $\mathrm{SiO}_{2}, \mathrm{TiO}_{2}$, $\mathrm{Al}_{2} \mathrm{O}_{3}, \mathrm{FeO}$ (= Fe total), $\mathrm{MgO}, \mathrm{CaO}, \mathrm{MnO}, \mathrm{Na}_{2} \mathrm{O}$ e $\mathrm{K}_{2} \mathrm{O}$ e os elementos-traço $\mathrm{Ba}, \mathrm{Sr}, \mathrm{V}, \mathrm{Y}, \mathrm{Zr}$ e S, complementadas com determinações de $\mathrm{CO}_{2}$ por analisador elementar de carbono (LECOCHN 1000).

\section{CONTEXTO GEOLÓGICO}

A área estudada localiza-se na interseção do Grupo Itaiacoca com o Arco de Ponta Grossa, uma estrutura mesozóica de soerguimento regional de direção N60W, contemporânea à abertura do Atlântico Sul (e.g. Almeida, 1983). Nesta região afloram rochas metamórficas e ígneas meso- a neoproterozóicas da Faixa de Dobramentos Ribeira (Hasui et al., 1975), diques de diabásio mesozóicos (Renne et al., 1996) e unidades fanerozóicas da Bacia do Paraná. O Grupo Itaiacoca forma um espesso pacote dobrado de rochas de baixo grau metamórfico, alongado na direção N40E (Figura 1), que se estende desde a região de Itaiacoca (Ponta Grossa, PR) até Itapeva (SP), entre os Complexos Graníticos Cunhaporanga, a W-NW, e Três Córregos, a E-SE (CPRM, 1977). Considerado inicialmente como parte do Grupo Açunguí (e.g. Bigarella, 1947), recebeu posteriormente as denominações de Formação Itaiacoca (Almeida, 1956; Soares, 1987; Soares et al., 1987), Grupo Itaiacoca (IPT, 1985) e Faixa Itaiacoca (Reis Neto, 1994).

A Zona de Cisalhamento Itapirapuã (ZCI; CPRM, 1977), de direção predominantemente $\mathrm{N} 40 \mathrm{E}$, divide localmente a Faixa Ribeira em dois blocos tectônicos. O bloco a sudeste da ZCI é composto pelo Complexo Granítico Três Córregos e por faixas de rochas supracrustais metamorfizadas em grau baixo a médio, localmente representadas pela Formação Água Clara (Marini, Trein, Fuck, 1967; Fassbinder, 1996). O bloco a noroeste é ocupado pelo Grupo Itaiacoca e pelo Complexo 


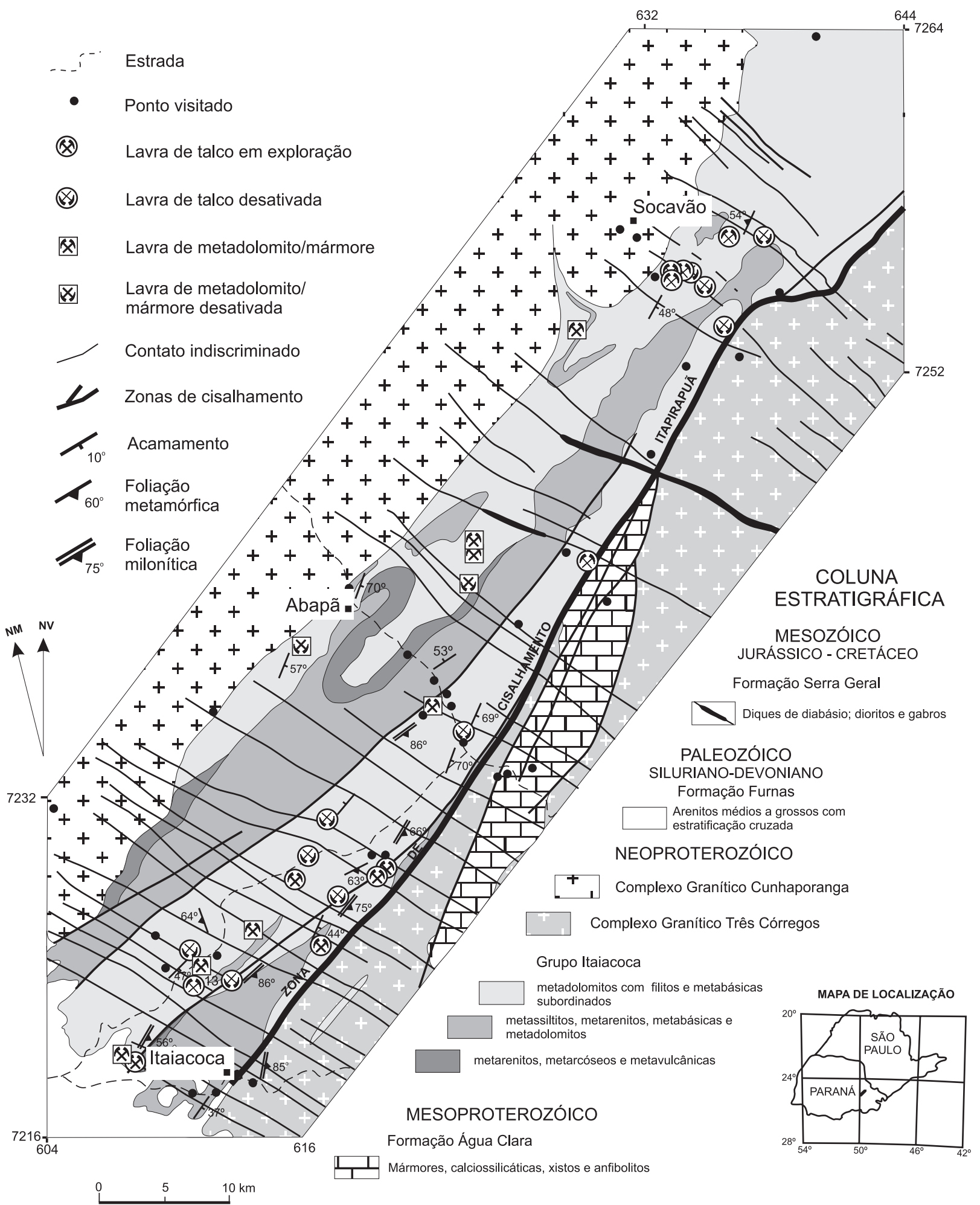

Figura 1. Mapa geológico do Grupo Itaiacoca entre Itaiacoca e Socavão (municípios de Ponta Grossa e Castro, nordeste do Estado do Paraná), com indicação das principais jazidas e ocorrências estudadas neste trabalho. Modificado de CPRM (1977). 
Granítico Cunhaporanga, além da bacia do Grupo Castro, situada fora da área da Figura 1. Estas rochas constituem o embasamento dos arenitos devoniano-silurianos da Formação Furnas da Bacia do Paraná, sendo todo o conjunto cortado por diques toleiíticos cretácicos de direção N40-50W, relacionados aos derrames basálticos da Formação Serra Geral. A região foi objeto de mapeamento geológico em diferentes escalas: Comissão da Carta Geológica do Paraná (e.g. Fuck, 1967), 1:150.000; CPRM (1977), 1:100.000; Guimarães (2000), 1:150.000; alunos do curso de Geologia da USP, em 1997 (Prazeres Filho et al., 1998), 1:25.000. Mapas geológicos de detalhe das principais jazidas e uma avaliação abrangente do Distrito Mineiro do talco no Paraná são apresentados em DNPM/MINEROPAR (1999).

O Grupo Itaiacoca é composto pelas seguintes unidades:

1. pacote predominantemente constituído de metadolomitos e mármores dolomíticos com intercalações de metabasitos, filitos e rochas metacarbonáticas com contribuição pelítica e psamítica (Formação Bairro dos Campos, Souza, 1990; Reis Neto, 1994; ou Formação Tanque Grande, Lima, 1993b);

2. pacote predominantemente metapelítico com intercalações de quartzitos (Formação Serra dos Macacos, Reis Neto, 1994);

3. pacote metarenítico a metarcoseano, com intercalações de rochas metavulcânicas e metavulcanoclásticas (Formação Abapã, Reis Neto, 1994; ou Formação Bairro da Estiva, Souza, 1990).

Os metadolomitos que hospedam as jazidas de talco constituem faixas espessas e homogêneas, de cor cinza e granulação fina, nas porções não afetadas por metamorfismo de contato ou cisalhamento. Sua composição mineralógica é relativamente homogênea, com leitos localmente mais ricos em quartzo ou em calcita. Testes de coloração diferencial de carbonatos indicam que calcita ocorre, na maioria das vezes, em teores $<5 \%$ vol. De forma subordinada observam-se leitos alternados de composição calcítica e dolomítica.

\section{HISTÓRIA METAMÓRFICA DO GRUPO ITAIACOCA}

O Grupo Itaiacoca foi afetado por quatro episódios metamórficos:

\section{Metamorfismo regional}

O Grupo Itaiacoca sofreu metamorfismo regional no Ciclo Brasiliano, no Neoproterozóico, entre 628 e 610 Ma, pouco após o preenchimento da bacia há 635 a 630 Ma, conforme idades $\mathrm{U} / \mathrm{Pb}$ em zircão de rochas metavulcânicas básicas
(Siga Jr. et al., 2003). O metamorfismo atingiu a facies xistoverde, zona da clorita, localmente alcançando a zona da biotita (Reis Neto, 1994; Prazeres Filho et al., 1998; Siga Jr. et al., 2003). Nas rochas metapelíticas e metavulcânicas, desenvolveu-se a foliação $S_{1}$ subparalela ao acamamento $\left(\mathrm{S}_{0}\right)$ e praticamente imperceptível nos metadolomitos, a não ser nas rochas metacarbonáticas impuras. A seguir, formaram-se dobras abertas assimétricas $\mathrm{D}_{2}$, com plano axial subvertical, às quais se associa foliação plano-axial $\mathrm{S}_{2}$. Houve formação de muscovita e clorita nas foliações $S_{1}$ e $S_{2}$ em metapelitos e filitos carbonáticos. Nos filitos, filitos carbonáticos e metavulcânicas a foliação $S_{2}$ ocorre como clivagem de crenulação, enquanto que nos metarenitos e metadolomitos desenvolveu-se uma clivagem espaçada. Para alguns autores (Soares, 1987; Lima, 1993b, 1997; DNPMMINEROPAR, 1999), a foliação $S_{1}$ teria se desenvolvido no decorrer do cisalhamento associado a processos de cavalgamento. Prazeres Filho et al. (1998) consideram que a recristalização metamórfica e deformação ocorreram em condições heterogêneas, não pervasivas.

Os metadolomitos puros não apresentam registros do metamorfismo regional, tendo preservado sua granulação submilimétrica, composição predominantemente dolomítica, coloração cinza pela presença de pequenas quantidades de matéria orgânica, além de estruturas sedimentares primárias, tais como estratificações e laminações sedimentares, de difícil identificação em superfícies não intemperisadas, raros leitos arenosos quartzosos, em geral descontínuos e complexamente deformados (Figura 2a), estruturas estromatolíticas e esteiras algais, oóides com delicados detalhes internos bem preservados. Os leitos de grãos detríticos de quartzo apresentam recristalização incipiente, mas não mostram sinais de reação com dolomita (Figura 2a), mesmo quando a alguns micrometros deles desenvolve-se talco em planos de cisalhamento ou fraturas de escala microscópica.

Não há evidências de campo ou petrográficas de que o metamorfismo regional tenha sido responsável pela geração de talco nos metadolomitos.

\section{Metamorfismo termal - Complexo Granítico Cunhaporanga}

O contato do Complexo Granítico Cunhaporanga (590 Ma; Prazeres Filho, 2000; Prazeres Filho et al., 2003) com o Grupo Itaiacoca é intrusivo. Nos filitos e metarritmitos próximos ao contato, desenvolveram-se porfiroblastos de andaluzita quiastolítica e granada, além de sillimanita (fibrolita) paralela à foliação $\left(S_{1}\right)$. Os metadolomitos cinzentos sofreram recristalização ao longo do contato, tornando-se mármores granoblásticos brancos, com veios e bolsões descontínuos com tremolita, quartzo, calcita metamórfica, 



Figura 2. Aspectos petrográficos de metadolomitos e mármores dolomíticos do Grupo Itaiacoca: a. leitos de quartzo granoblástico em metadolomito (amostra PTI 15A, lado maior = 10,2 mm, polarizadores cruzados); b. tremolita fibro-radiada em metadolomito cisalhado, incipientemente talcificado (amostra PTI 22L, lado maior $=5,1 \mathrm{~mm}$, polarizadores cruzados); c. lente de metadolomito residual em talco xisto (amostra PTI 02 $\mathrm{H} 2$, lado maior $=10,2 \mathrm{~mm}$, polarizadores cruzados); d. porfiroblasto de tremolita em mármore dolomítico, com franja de calcita (amostra PTI 07J1, lado maior = 1,3 mm, polarizadores cruzados); e. lentes zonadas em metadolomito incipientemente talcificado, com núcleos de calcita (granoblástica, mais clara) e bordas de talco (mais escuras) (amostra PTI 06A, lado maior $=1,6 \mathrm{~mm}$, polarizadores cruzados); $\mathbf{f}$. rede de veios zonados em padrão poligonal em metadolomito incipientemente talcificado, com calcita no núcleo e talco (franjas escuras) nas bordas (amostra PTI 42E, lado maior $=10,2 \mathrm{~mm}$, polarizadores cruzados). 
talco, diopsídio e forsterita, freqüentemente com zoneamento concêntrico, com paragêneses de mais alto grau nos núcleos, envoltas por paragêneses retrometamórficas. A tremolita ocorre também em porfiroblastos aciculares milimétricos isolados, alinhados ao longo de fraturas, às vezes acompanhada de calcita metamórfica (Figura 2d) ou em parte substituída por talco. O contato das rochas metassedimentares com os granitos foi localmente afetado por falhas menores, mas prevalece seu caráter intrusivo com evidências de percolação de fluidos aquosos com alta atividade de sílica nas rochas encaixantes. A percolação foi não pervasiva, controlada por descontinuidades estruturais tais como planos de acamamento e sistemas de fraturas. Não foi possível traçar em campo as isógradas ao longo do contato, em parte pela descontinuidade das exposições, em parte porque a blastese e a distribuição dos minerais-índice (talco, tremolita, diopsídio, forsterita) está intimamente associada aos canais preferenciais seguidos pelos fluidos aquosos, os quais sofreram modificações composicionais em função da interação com as rochas encaixantes.

Os mármores dolomíticos formados pelo metamorfismo de contato são usados na indústria cerâmica pelo seu elevado conteúdo em $\mathrm{Mg}$ e excelente alvura. Não há evidências que vinculem jazidas de talco a este episódio metamórfico.

\section{Metamorfismo dinâmico - Zona de Cisalhamento Itapirapuã}

O metamorfismo dinâmico ocorreu ao longo das ramificações da Zona de Cisalhamento Itapirapuã (ZCI), que define o contato tectônico do Grupo Itaiacoca com o Complexo Granítico Três Córregos (630 Ma, Prazeres Filho et al., 2003) e a Formação Água Clara (1500 Ma, Fassbinder, 1996; Weber et al., 2004). A região de contato é complexamente estruturada, apresentando fatias tectonizadas de filitos e quartzitos, algumas delas possivelmente provenientes da Formação Água Clara. Não foram observadas evidências de metamorfismo termal. A abundância de veios de quartzo concordantes, deformados em grau variável, e discordantes indica aporte de fluidos hidrotermais ricos em sílica através da zona de cisalhamento em todas as etapas de sua evolução. Corpos de metabasitos em contato com os metadolomitos talcificados sofreram alteração hidrotermal com epidotização generalizada. Nos metadolomitos, o metamorfismo hidrotermal associado à deformação heterogênea promoveu intensa talcificação, transformandoos em talco xistos.

As maiores lavras de talco da região, como as Minas Grande e Paranaense (antiga São José), localizam-se ao longo de uma ramificação da ZCI (Figura 1), que segue paralela ao contato tectônico entre metadolomitos e granitos e se prolonga por sob os arenitos da Formação Furnas.
Localmente, planos de cisalhamento de direções NNW ou NS apresentam concentrações menores de talco.

\section{Metamorfismo termal - diques de diabásio do Arco de Ponta Grossa}

A intrusão dos diques de diabásio cretácicos causou um segundo episódio termometamórfico, que se desenvolveu com limitada percolação de fluidos, em faixas milimétricas a centimétricas e em fraturas nas zonas marginais dos diques, gerando bandas irregulares de granulação muito fina, pretocastanho-verde, contendo serpentina nos metadolomitos contíguos. Megaxenólitos de metadolomito em diques espessos contêm serpentina crisotila, em parte possivelmente pseudomorfa sobre olivina, e veios de brucita. Não houve formação de talco nas auréolas metamórficas destes diques, que truncam faixas de talco xisto. Nas proximidades de diques mais possantes, o metadolomito sofreu recristalização, transformando-se em mármore dolomítico e calcítico branco a distâncias de até vários metros do contato. Em alguns casos, a recristalização foi condicionada pela estratificação, produzindo leitos alternados de mármore calcítico branco e de metadolomito cinza fino. Metadolomitos previamente talcificados de modo incipiente foram transformados em mármores calcíticosdolomíticos talcosos brancos, de grande interesse para a indústria cerâmica.

\section{PADRṌES DE OCORRÊNCIA DO TALCO}

Foram identificados quatro padrões de ocorrência do talco nos metadolomitos e mármores dolomíticos, sem considerar feições menores de retrabalhamento dos depósitos (talco coluvionar e cárstico, e.g. Lima, 1993a, ou talco de alteração superficial, e.g. DNPM-MINEROPAR, 1999):

a. talco xistos associados às ramificações da ZCI, com lamelas bem desenvolvidas de talco de coloração branca, rosa, bege, verde, cinza e até preta. As faixas de talco xisto têm várias centenas a milhares de metros de extensão, com largura de dezenas de metros a alguns centímetros ou milímetros. A foliação anastomosada envolve núcleos residuais lenticularizados de metadolomito cisalhado (Figura 3a), localmente silicificado, e lentes sin-tectônicas de calcita, quartzo e eventualmente tremolita fibrosa (Figura 2b) e crisotila em proporções variadas. A talcificação é auto-similar em diversas escalas, com lentes carbonáticas envoltas por planos anastomosados de talco (Figura 2c). O talco xisto está concentrado ao longo do contato sudeste do Grupo Itaiacoca, principalmente na sua parte meridional, na região de Itaiacoca, Ponta Grossa (Figura 1), onde se localizam as jazidas de talco mais expressivas da região; 
b. metadolomitos não cisalhados com talcificação incipiente, não pervasiva, na forma de leitos, veios, filetes e filmes de talco fino em descontinuidades estruturais como planos de estratificação, clivagens plano-axiais espaçadas e redes irregulares de fraturas (Figura 3b). Estas feições ocorrem em rochas pouco ou não afetadas pelas zonas de cisalhamento, freqüentemente em cavas de lavras exauridas ou em núcleos de metadolomitos não talcificados em meio a bolsões de talco maciço fino. Nas imediações da ZCI são freqüentes as ocorrências de metadolomitos intensamente fraturados, configurando brechas protocataclásticas, com filmes de talco em alguns ramos da rede de fraturas, possivelmente formados por fluidos oriundos da ZCI;

c. metadolomitos não-cisalhados com bolsões irregulares de talco muito fino, maciço, branco a variegado em tons bege a rosa, de aspecto argiloso, plástico quando úmido ou pulverulento quando seco. O metadolomito cinzento transiciona para estes bolsões de maneira gradual, preservando freqüentemente a estratificação, sugerindo uma substituição estática (Figura 3c). Estes bolsões não têm relação espacial evidente com zonas de cisalhamento, intrusões graníticas ou diques de diabásio. As jazidas de talco maciço fino são atualmente as mais lavradas, devido à relação custo/benefício favorável oferecida pelo minério de extração mais simples, realizada através de escavação mecanizada, sem a necessidade de seleção manual, como nas lavras de talco foliado. As lavras de talco maciço distribuem-se predominantemente na região de Socavão, município de Castro, mas ocorrem também na região de Itaiacoca. Muitas das lavras exauridas, sem evidências de talco foliado, devem ter sido deste tipo de talco;

d. talco retrometamórfico associado às lentes zonadas com forsterita, diopsídio, tremolita, quartzo e calcita (Figura 3d) e aos porfiroblastos de tremolita nos mármores dolomíticos da auréola de contato do Complexo Granítico Cunhaporanga. Este talco não constitui concentrações de interesse econômico.

As diferenças entre os tipos de talco (a) e (c) refletem-se também no estilo dos blocos deixados para trás após a retirada do minério. No caso do talco foliado (tipo a), os blocos contêm restos de metadolomito cisalhado parcialmente talcificado e estão alinhados segundo a direção das zonas de cisalhamento. Nas cavas de talco maciço fino (tipo c), os blocos residuais são irregulares e apresentam acamamento basculado com dobras abertas, com feições de talcificação incipiente ao longo da estratificação e de estruturas estilolíticas. A dicotomia de tipos de talco nas jazidas do Grupo Itaiacoca foi mencionada por Araújo et al. (1987) e Gondim e Loyola (2002), quando se referem a dois tipos de minério lavrados, respectivamente, nos municípios de Ponta Grossa (distrito de Itaiacoca) e Castro (distrito de Socavão): o primeiro seria mais cristalino, lamelar-placóide, untuoso, com maior variedade e freqüência de minerais associados (tremolita, quartzo, clorita, montmorillonita), e formaria depósitos de maior volume, enquanto o segundo seria mais fino, pulverulento, microcristalino, com assembléia de minerais associados mais simples (clorita e quartzo) e de menor volume, ocorrendo em bolsões menores, porém mais numerosos.

\section{MINERALOGIA DOS MINÉRIOS DE TALCO}

As fases minerais associadas ao talco são principalmente quartzo, calcita e dolomita. Foram identificados ainda serpentina, tremolita, clorita, brucita e outros filossilicatos menos abundantes. A análise dos minérios de talco prébeneficiados, cominuídos manualmente, com seleção granulométrica e mineralógica rudimentar realizada através de peneiramento em rampas, estocados no pátio das minerações, indicou que apenas $18 \%$ dos minérios analisados correspondem a talco puro, provenientes tanto das jazidas de talco xisto como de talco maciço fino. Quartzo é a fase mineral mais comum associada ao talco nos minérios, ocorrendo em aproximadamente $60 \%$ das amostras.

A tremolita foi detectada apenas em minérios provenientes de talco xistos da área de Itaiacoca, onde a sua variedade fibrosa-acicular foi identificada in situ em várias jazidas (Figura 2b). A tremolita não foi detectada em minérios de talco fino maciço da região de Socavão.

Os carbonatos acompanham sistematicamente o talco nas jazidas, sendo calcita a fase carbonática mais freqüente encontrada nos minérios, com dolomita praticamente ausente. Este fato se deve provavelmente ao modo de ocorrência de ambos, com a dolomita apresentando-se como lentes centi- a decimétricas em meio aos talco xistos sendo, portanto, separada mais facilmente no processo de seleção manual, enquanto a calcita ocorre intimamente associada ao talco, em filetes e grãos menores intersticiais.

Outros minerais reconhecidos por DRX foram serpentina, clorita e argilominerais (montmorillonita, saponita). Pirita foi reconhecida apenas macroscopicamente em raras amostras.

\section{QUÍMICA DE ROCHA TOTAL}

As análises químicas de rocha total são apresentados na Tabela 1. Foram analisados:
a. metadolomitos não talcificados;
b. metadolomitos incipientemente talcificados;
c. metadolomitos intensamente talcificados;
d. talco xistos;
e. tremolita mármores dolomíticos do contato com o

Complexo Granítico Cunhaporanga;

f. talco maciço fino, pulverulento. 

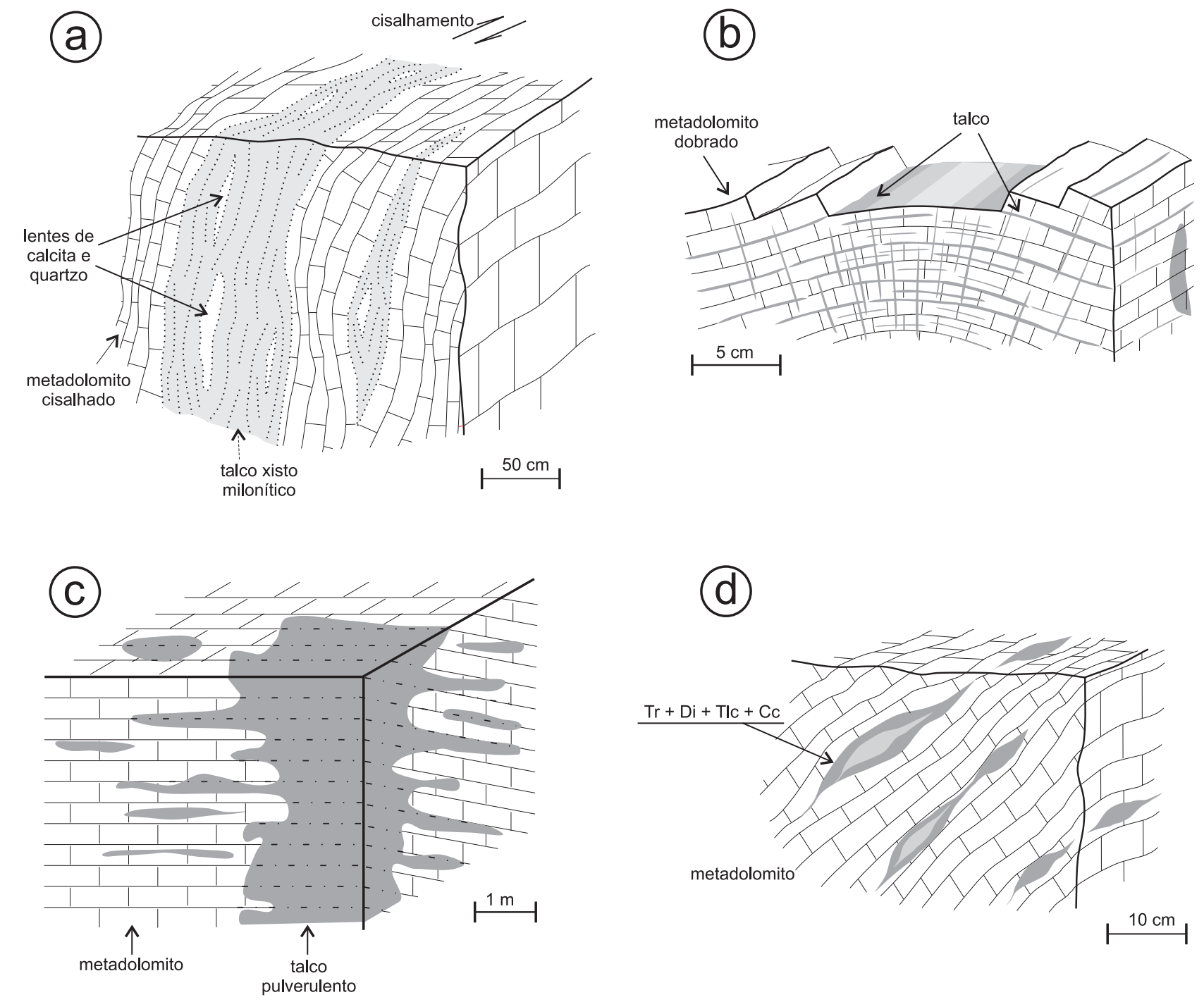

(d)

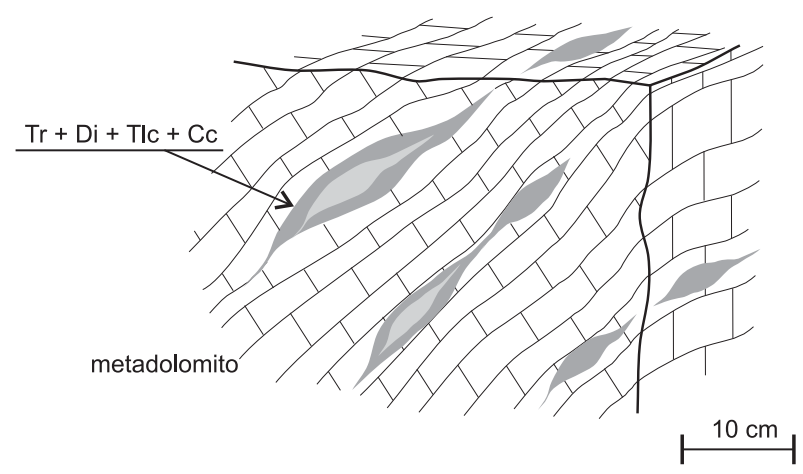

Figura 3. Padrões de ocorrência de talco: $\mathbf{a}$. talco xistos associados à $\mathrm{ZCl} ; \mathbf{b}$. metadolomito incipientemente talcificado ao longo de descontinuidades estruturais; $\mathbf{c}$. bolsões de talco fino, maciço, pulverulento em metadolomitos; $\mathbf{d}$. talco retrometamórfico associado a lentes de olivina, diopsídio, tremolita, calcita e quartzo na auréola de contato do Complexo Granítico Cunhaporanga ( $\mathbf{T r}=$ tremolita; $\mathbf{D i}=$ diopsídio; $\mathbf{T l c}=$ talco; $\mathbf{C c}=$ calcita). 
Tabela 1. Análises químicas de talco xistos, metadolomitos, tremolita mármores e metadolomitos com grau variado de talcificação do Grupo Itaiacoca.

\begin{tabular}{|c|c|c|c|c|c|c|c|c|c|c|c|c|c|c|c|}
\hline \multirow{2}{*}{ Amostra } & \multicolumn{6}{|c|}{ Metadolomito não talcificado } & \multicolumn{9}{|c|}{ Metadolomito incipientemente talcificado } \\
\hline & PTI01A & PTI15B & PTI37AA & PTI39A & PTI48 & PTI54A1 & PTI05D & PTI06B & PTI06D1 & PTI06D2 & PTI06E & PTI22C & PTI22D2 & PTI22L & PTI35C \\
\hline $\mathrm{SiO}_{2}(\%)$ & 0,05 & 33,2 & 4,85 & 15,3 & 0,53 & 1,43 & 0 & 4,21 & 13,1 & 1,95 & 19,1 & 9,5 & 6,93 & 5,17 & 4,77 \\
\hline $\mathrm{TiO}_{2}$ & $<0,01$ & $<0,01$ & $<0,01$ & $<0,01$ & $<0,01$ & $<0,01$ & $<0,01$ & $<0,01$ & $<0,01$ & $<0,01$ & $<0,01$ & $<0,01$ & $<0,01$ & $<0,01$ & 0,03 \\
\hline $\mathrm{Al}_{2} \mathrm{O}_{3}$ & 0,06 & 0,12 & 0,16 & 0,33 & 0,06 & 0,29 & 0,07 & 0,1 & 0,07 & 0,08 & 0,09 & 0,34 & 0,14 & 0,15 & 0,77 \\
\hline $\mathrm{FeO}_{\mathrm{t}}$ & 0,06 & 0,05 & 0,09 & 0,16 & 0,04 & 0,11 & 0,1 & 0,08 & 0,05 & 0,05 & 0,05 & 0,14 & 0,1 & 0,12 & 0,29 \\
\hline $\mathrm{MnO}$ & 0,01 & $<0,01$ & $<0,01$ & $<0,01$ & $<0,01$ & $<0,01$ & $<0,01$ & $<0,01$ & $<0,01$ & $<0,01$ & 1,27 & $<0,01$ & $<0,01$ & $<0,01$ & $<0,01$ \\
\hline $\mathrm{MgO}$ & 21,5 & 14,4 & 20,8 & 18,5 & 21 & 20,8 & 22,8 & 21,3 & 20,1 & 22,1 & 20,1 & 19,3 & 18,8 & 20,2 & 20 \\
\hline $\mathrm{CaO}$ & 31,4 & 21,7 & 31,9 & 26,4 & 32,5 & 31,4 & 31,4 & 31 & 29,6 & 32 & 29 & 31,1 & 32,5 & 31,91 & 32,2 \\
\hline $\mathrm{Na}_{2} \mathrm{O}$ & $<0,01$ & $<0,01$ & 0,05 & $<0,01$ & 0,02 & 0,04 & $<0,01$ & $<0,01$ & $<0,01$ & $<0,01$ & $<0,01$ & $<0,01$ & $<0,01$ & $<0,01$ & $<0,01$ \\
\hline $\mathrm{K}_{2} \mathrm{O}$ & $<0,03$ & $<0,03$ & $<0,03$ & 0,11 & $<0,03$ & $<0,03$ & $<0,03$ & $<0,03$ & $<0,03$ & $<0,03$ & $<0,03$ & $<0,03$ & $<0,03$ & $<0,03$ & 0,08 \\
\hline $\mathrm{P}_{2} \mathrm{O}_{5}$ & 0,01 & 0,01 & 0,01 & 0,01 & 0,07 & $<0,01$ & 0,01 & $<0,01$ & $<0,01$ & $<0,01$ & $<0,01$ & 0,01 & 0,01 & 0,01 & 0,01 \\
\hline $\mathrm{H}_{2} \mathrm{O}+$ & 0,08 & 0,09 & nd & 0,04 & nd & nd & 0,02 & 0,44 & 0,32 & nd & 1,27 & 0,54 & 0,54 & 0,71 & 1,13 \\
\hline $\mathrm{CO}_{2}$ & 46,9 & 30,4 & nd & 39,1 & nd & nd & 45,3 & 43,2 & 37 & 44,1 & 30,5 & 39 & 41 & 41,9 & 41,3 \\
\hline LOI & 46,6 & 31 & 43 & 40,06 & 46,6 & 46,1 & 45,5 & 44 & 37,1 & 44,5 & 32,1 & 40 & 41,8 & 42,6 & 42,6 \\
\hline $\mathrm{Ba}(\mathrm{ppm})$ & $<10$ & $<10$ & $<10$ & $<10$ & $<10$ & $<10$ & $<10$ & $<10$ & $<10$ & $<10$ & $<10$ & 11 & 9 & 11 & $<10$ \\
\hline $\mathrm{Sr}$ & 27 & 21 & 39 & 41 & 22 & 16 & 42 & 26 & 30 & 26 & 36 & 32 & 32 & 31 & 49 \\
\hline V & $<15$ & $<15$ & $<15$ & $<15$ & $<15$ & $<15$ & $<15$ & $<15$ & $<15$ & $<15$ & $<15$ & $<15$ & $<15$ & $<15$ & $<15$ \\
\hline$Y$ & $<10$ & $<10$ & $<10$ & $<10$ & $<10$ & $<10$ & $<10$ & $<10$ & $<10$ & $<10$ & $<10$ & $<10$ & $<10$ & $<10$ & $<10$ \\
\hline $\mathrm{Zr}$ & $<25$ & $<25$ & $<25$ & $<25$ & $<25$ & $<25$ & $<25$ & $<25$ & $<25$ & $<25$ & $<25$ & $<25$ & $<25$ & $<25$ & $<25$ \\
\hline $\mathrm{S}$ & 275 & 322 & nd & 300 & nd & nd & 301 & 284 & 313 & 324 & 320 & 329 & 314 & 304 & 306 \\
\hline
\end{tabular}

\begin{tabular}{|c|c|c|c|c|c|c|c|c|c|}
\hline \multirow[t]{2}{*}{ Amostra } & \multicolumn{2}{|c|}{$\begin{array}{c}\text { Metadolomito } \\
\text { intensamente talcificado }\end{array}$} & \multicolumn{2}{|c|}{ Talco xisto } & \multicolumn{3}{|c|}{ Talco fino maciço } & \multicolumn{2}{|c|}{ Tremolita mármore } \\
\hline & PTI02G & PTI22F & PTI02B & PT108AB2 & PTI46E & PTI46F & PTI46G & PTI05B & PTI47A \\
\hline $\mathrm{SiO}_{2}(\%)$ & 42,9 & 32,6 & 64,2 & 62,9 & 57,6 & 62,6 & 60 & 2,62 & 1,08 \\
\hline $\mathrm{TiO}_{2}$ & $<0,01$ & $<0,01$ & $<0,01$ & 0,02 & 0,26 & 0,02 & 0,18 & $<0,01$ & $<0,01$ \\
\hline $\mathrm{Al}_{2} \mathrm{O}_{3}$ & 0,04 & 0,17 & 0,04 & 0,42 & 13,3 & 0,39 & 4,7 & 0,18 & 0,04 \\
\hline $\mathrm{FeO}_{\mathrm{t}}$ & 0,05 & 0,24 & 0,03 & 0,45 & 1,77 & 0,32 & 0,93 & 0,07 & 0,05 \\
\hline $\mathrm{MnO}$ & $<0,01$ & $<0,01$ & $<0,01$ & 0,03 & 0,04 & 0,02 & 0,01 & $<0,01$ & $<0,01$ \\
\hline $\mathrm{MgO}$ & 21,1 & 15,7 & 31 & 31,5 & 19,6 & 31,5 & 27,3 & 22,5 & 21,3 \\
\hline $\mathrm{CaO}$ & 18,4 & 28 & $<0,01$ & 0,02 & $<0,006$ & 0,02 & 0,31 & 30,2 & 30,12 \\
\hline $\mathrm{Na}_{2} \mathrm{O}$ & $<0,01$ & 0,04 & $<0,01$ & 0,03 & 0,03 & 0,03 & 0,11 & $<0,01$ & $<0,01$ \\
\hline $\mathrm{K}_{2} \mathrm{O}$ & $<0,03$ & $<0,03$ & $<0,03$ & $<0,03$ & 0,05 & $<0,03$ & 1,14 & $<0,03$ & $<0,03$ \\
\hline $\mathrm{P}_{2} \mathrm{O}_{5}$ & 0,01 & 0,01 & 0,01 & $<0,01$ & 0,01 & $<0,01$ & 0,03 & 0,01 & $<0,01$ \\
\hline $\mathrm{H}_{2} \mathrm{O}+$ & 2,38 & 1,82 & 4,28 & nd & nd & nd & nd & 0,33 & nd \\
\hline $\mathrm{CO}_{2}$ & 15,2 & 22,1 & 0,82 & nd & nd & nd & nd & 44,2 & 46,8 \\
\hline LOI & 18,3 & 24,2 & 4,8 & 5,16 & 8,74 & 5,24 & 6,21 & 44,4 & 46,9 \\
\hline Total & 100,7 & 100,9 & 100 & 100,4 & 101,3 & 100,1 & 100,9 & 99,9 & 99,5 \\
\hline $\mathrm{Ba}(p p m)$ & $<10$ & 11 & $<10$ & $<10$ & 46 & 17 & 37 & $<10$ & $<10$ \\
\hline $\mathrm{Sr}$ & 111 & 41 & $<5$ & $<5$ & $<5$ & $<5$ & $<5$ & 37 & 26 \\
\hline V & $<15$ & $<15$ & $<15$ & $<15$ & 18 & $<15$ & 32 & $<15$ & $<15$ \\
\hline Y & $<10$ & $<10$ & $<10$ & $<10$ & 28 & $<10$ & 102 & $<10$ & $<10$ \\
\hline $\mathrm{Zr}$ & $<25$ & $<25$ & $<25$ & $<25$ & 41 & $<25$ & 38 & $<25$ & $<25$ \\
\hline$S$ & 317 & 305 & 294 & nd & nd & nd & nd & 290 & 272 \\
\hline
\end{tabular}


Nas amostras de metadolomitos e mármores dolomíticos não talcificados, o teor de sílica varia de $<1 \%$ até cerca de $15 \%$ em peso e corresponde a quartzo detrítico e, eventualmente, a vênulas de quartzo. A variação na composição química é coerente com as observações petrográficas, sendo que o aumento no grau de talcificação traduz-se num aumento do teor de $\mathrm{SiO}_{2}$ e concomitante redução de $\mathrm{CaO}$ e $\mathrm{CO}_{2}$ (Figura 4).

A composição química simples das amostras e o caráter metassomático da talcificação impossibilitam a realização de um balanço de massas, por não haver componentes imóveis que possam servir de referência. Elementos traço como Co, Cr e Ni, considerados por Shin e Lee (2002) como relativamente imóveis para a construção de diagramas tipo "isocon" para avaliar a mobilidade relativa dos demais constituintes, não foram analisados.
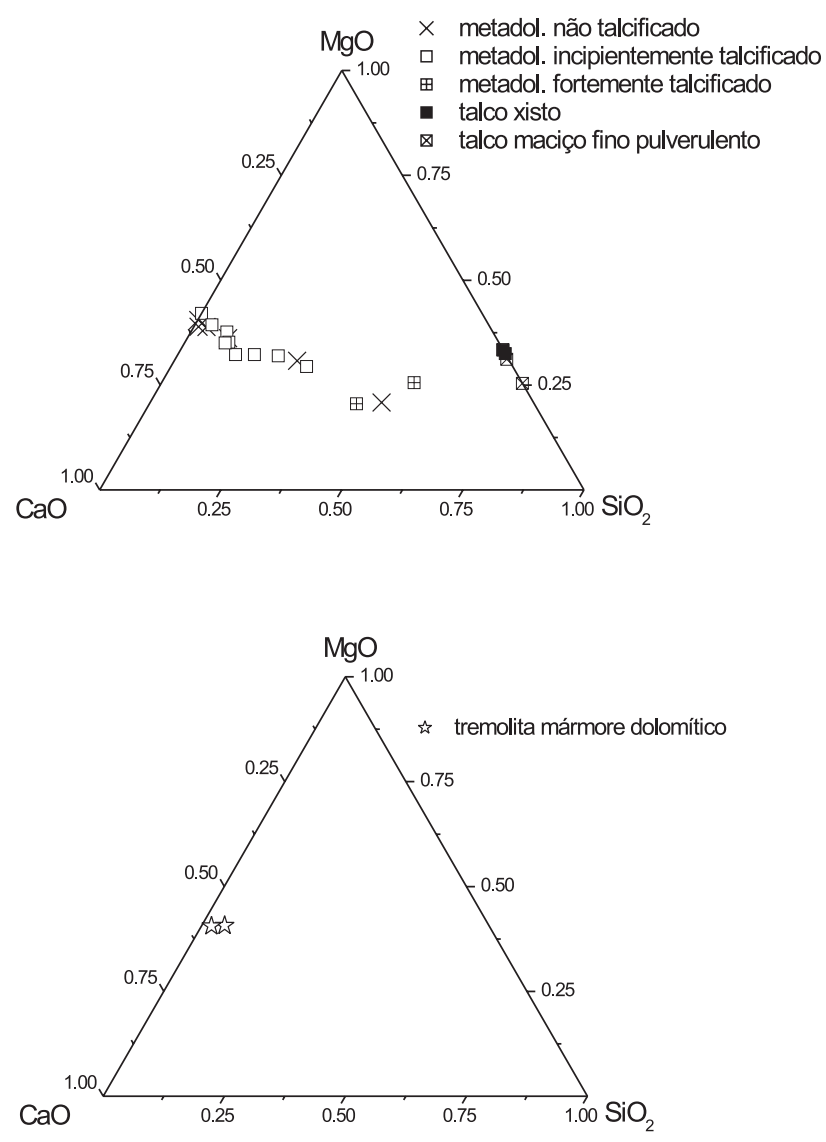

Figura 4. Diagrama $\mathrm{CaO}-\mathrm{MgO}-\mathrm{SiO}_{2}$ para amostras de metadolomitos, talco xistos, metadolomitos com grau variado de talcificação e tremolita mármores dolomíticos do Grupo Itaiacoca.
Apesar do consenso em torno da mobilidade de $\mathrm{Si}, \mathrm{Ca}$, $\mathrm{H}_{2} \mathrm{O}$ e $\mathrm{CO}_{2}$, são conflitantes as considerações sobre a mobilidade do $\mathrm{Mg}$, freqüentemente considerado como adicionado ao sistema durante o processo metassomático (e.g. Anderson, Mogk, Childs, 1990). Os demais elementos analisados apresentam distribuição irregular $(\mathrm{Al}, \mathrm{Fe})$ ou ocorrem em teores inferiores ou próximos aos limites de detecção dos métodos analíticos usados (Ba, V, Y, Zr). Na zona de cisalhamento, a relação volumétrica entre o metadolomito precursor e o talco xisto não pode ser avaliada com segurança, por falta de marcadores confiáveis.

\section{GEOTERMOMETRIA DE CARBONATOS}

As temperaturas de talcificação foram estimadas através do teor de Mg na calcita metamórfica (Puhan, 1995). Não foram considerados pares dolomita-calcita (e.g. Anovitz e Essene 1987; Letargo et al., 1995) por não ser possível assegurar, com base em critérios texturais, que os pares estejam em equilíbrio.

Alguns cristais de calcita apresentam grande dispersão dos teores de Mg (Tabela 2). A presença de lamelas de dolomita exsolvida a partir de calcita magnesiana precursora de alta temperatura foi descartada através de análises por MEV. O padrão de variação do teor de Mg na calcita é irregular, ocorrendo tanto variação intergrãos como intragrãos, sendo que a variação intergrãos tende a ser mais acentuada. Em rochas metacarbonáticas da auréola de contato de uma intrusão granítica, Cook e Bowman (1994) descreveram variação composicional intergrãos mais acentuada, sugerindo reequilíbrio retrógrado grão a grão. Por esta razão, os autores consideram que apenas os teores mais elevados de $\mathrm{Mg}$ sejam representativos das temperaturas do pico metamórfico. As variações nos teores de Mg em cristais de calcita de uma mesma amostra sugerem reequilíbrio das composições representativas das temperaturas mais elevadas em conseqüência de processos metamórficos evanescentes, de temperaturas mais baixas. A identificação deste reequilíbrio tardio é inviável por critérios texturais.

Os valores extremos de $\mathrm{X}_{\mathrm{Mg}}$ e temperaturas estimadas de cristalização de calcita em amostras do Grupo Itaiacoca são apresentados na Tabela 2. As estimativas de temperatura de pico em jazidas de talco xistos variam entre 410 e $425^{\circ} \mathrm{C}$, compatíveis com a formação de tremolita. A estimativa mais elevada de temperatura $\left(530^{\circ} \mathrm{C}\right)$ foi obtida em calcita de mármore dolomítico com tremolita e diopsídio da auréola de contato do Complexo Granítico Cunhaporanga. Estimativas de temperaturas da ordem de $<200$ a $220^{\circ} \mathrm{C}$ foram obtidas em praticamente todas as amostras, representando provavelmente o reequilíbrio tardio da calcita. 
Tabela 2. Teores máximos e mínimos de $M g$ em calcita $\left(X_{M g}\right)$ e temperaturas correspondentes estimadas (Puhan, 1995) para amostras de talco xistos, metadolomitos talcificados e tremolita mármores dolomíticos do Grupo Itaiacoca.

\begin{tabular}{lcc}
\hline Amostra & XMg & T $\left({ }^{\circ} \mathrm{C}\right)$ \\
\hline PTI 02 AA & $0,017-0,028$ & $\sim 350-420$ \\
PTI 02 AB1 & $0,009-0,012$ & $\sim 290-310$ \\
PTI 02 CA & $0,009-0,011$ & $\sim 300$ \\
PTI 02 CC & $0,006-0,027$ & $\sim 250-410$ \\
PTI 02 Cl & $0,003-0,016$ & $<200-340$ \\
PTI 07 J1 & $0,004-0,054$ & $\sim 220-530$ \\
PTI 22 BD & $0,010-0,013$ & $\sim 295-320$ \\
PTI 22 D1 & $0,022-0,026$ & $\sim 380-410$ \\
PTI 22 L & $0,018-0,028$ & $\sim 360-420$ \\
PTI 38 E & 0,004 & $\sim 220$ \\
PTI 40 A & $0,002-0,008$ & $<200-280$ \\
PTI 42 A & $0,004-0,027$ & $\sim 220-420$ \\
PTI 42 B & $0,002-0,009$ & $<200-290$ \\
PTI 43 C & $0,007-0,028$ & $\sim 270-425$ \\
PTI 55 C & $0,003-0,015$ & $<200-340$ \\
\hline
\end{tabular}

\section{METAMORFISMO E TALCIFICAÇÃO NO GRUPO ITAIACOCA}

Os primeiros trabalhos sobre a formação de talco por metamorfismo de dolomitos impuros devem-se a Bowen (1940) e Tilley (1948), que abordaram rochas dolomíticas silicosas afetadas por fluidos aquosos, sendo o quartzo detrítico presente no dolomito a fonte de sílica para a formação de talco. Entretanto, este processo não é suficiente para formar jazidas. A formação de jazidas de talco a partir de dolomitos implica percolação de fluidos aquosos em volume suficiente para promover o aporte de $\mathrm{SiO}_{2}$ e a retirada de $\mathrm{Ca}$ e $\mathrm{CO}_{2}$, transformando a rocha cálcio-magnesiana carbonática anidra em magnesiana silicosa hidratada. A maioria dos depósitos de talco descritos na literatura está relacionada a rochas dolomíticas associadas a zonas de cisalhamento de amplitude regional (Blount e Vassiliou, 1980; Prochaska, 1989; Anderson, Mogk, Childs, 1990; Prochaska, Mogessie, Raith, 1992; Schandl, Sharara, Gorton, 1999; Hecht et al., 1999; Tornos e Spiro, 2000; Shin e Lee, 2002), sendo menos freqüentes os estudos de jazidas ligadas a rochas metaultramáficas (e.g. El-Sharkawy, 2000). De modo similar, as relações de campo no Grupo Itaiacoca indicam que o principal episódio de talcificação esteve vinculado a cisalhamento e metamorfismo hidrotermal na borda sudeste do Grupo. As principais jazidas da região situam-se sobre um dos ramos da ZCI, na região de Itaiacoca (Figura 1), onde o minério é talco xisto com foliação anastomosada, lentes de metadolomito, concentrações localizadas de calcita e ocasionalmente tremolita interplanar (Figura 2b).

As estimativas das condições de temperatura, pressão e fração molar de $\mathrm{CO}_{2}$ do fluido de talcificação são dificultadas pelas divergências existentes nas curvas de equilíbrio do sistema $\mathrm{MgO}-\mathrm{SiO}_{2}-\mathrm{CaO}-\mathrm{H}_{2} \mathrm{O}-\mathrm{CO}_{2}$ disponíveis na literatura. Trabalhos mais antigos (Gordon e Greenwood, 1970; Skippen, 1974; Slaughter et al., 1975; Rice, 1977; Eggert e Kerrick, 1981) fornecem campos de estabilidade determinados experimentalmente sob condições diversas, que divergem entre si e em relação aos trabalhos mais recentes (Evans e Guggenheim, 1988; Spear, 1993; Holness, 1992), onde as curvas de equilíbrio são calculadas a partir de conjuntos de dados termodinâmicos internamente coerentes. Também há divergências quanto à influência da pressão total sobre o campo de estabilidade da associação talco + calcita. Skippen (1974) e Skippen e Trommsdorff (1986) apresentam resultados experimentais indicando contração do campo de estabilidade de talco + calcita com a diminuição da pressão total, enquanto que Slaughter et al., (1975) chegam a resultado oposto, onde o campo de estabilidade seria maior a pressões menores. Adicionalmente, a presença de $\mathrm{F}$ no fluido metamórfico deslocaria os respectivos pontos invariantes para frações molares de $\mathrm{CO}_{2}$ maiores (Evans e Guggenheim, 1988; Holness, 1992), ampliando o campo de estabilidade de minerais como talco, tremolita e flogopita.

A origem e as condições físico-químicas dos fluidos da talcificação geralmente são mencionadas de maneira genérica na literatura. Em alguns casos, a fonte dos fluidos é atribuída a intrusões graníticas (Prochaska et al., 1992; El-Sharkawy, 2000; Shin e Lee, 2002). As temperaturas estimadas por meio de inclusões fluidas, isótopos estáveis ou equilíbrios termodinâmicos de reações minerais são inferiores a $500^{\circ} \mathrm{C}$ e as frações molares de $\mathrm{CO}_{2}$ em geral são baixas (175 a $350^{\circ} \mathrm{C}$, Prochaska et al., 1992; $\mathrm{T}_{\max }<500^{\circ} \mathrm{C}$ e $\mathrm{X}_{\mathrm{CO} 2}<0,2$, Schandl, Sharara, Gorton, 1999; 250 a $400^{\circ} \mathrm{C}$, baixa $\mathrm{X}_{\mathrm{CO} 2}$, Hecht et al., 1999; 380 a $400^{\circ} \mathrm{C}$, Shin e Lee, 2002). Há registros de talcificação retrometamórfica sobreposta a paragêneses cálcio-silicáticas de temperaturas mais elevadas (Schandl et al., 1999; Shin e Lee, 2002). Nos depósitos de talco de Winterboro (Alabama, EUA), Blount e Vassiliou (1980) sugerem uma substituição do metadolomito por talco a baixas temperaturas através de soluções hidrotermais infiltradas ao longo de fraturas. Em algumas ocorrências, a talcificação 
se seguiria imediatamente ao processo de dolomitização (Hecht et al., 1999).

A evolução geológica dos metadolomitos do Grupo Itaiacoca está resumida na Figura 5. Segundo Siga Jr. et al., (2003) a sedimentação teria ocorrido no Neoproterozóico. A dolomitização possivelmente foi concomitante ou imediatamente posterior à sedimentação, não estando vinculada à talcificação. No Ciclo Brasiliano ocorreu metamorfismo regional em facies xisto verde, zona da clorita (localmente zona da biotita) e deformação em dobras abertas, não causando transformações significativas nos metadolomitos, posto que o quartzo detrítico permaneceu em equilíbrio com a dolomita (Figura 2a). Os episódios metamórficos seguintes, ainda no Neoproterozóico, foram concentrados nas bordas do Grupo Itaiacoca. A sudeste houve o desenvolvimento da ZCI no contato com o Complexo Granítico Três Córregos, não sendo conhecidos registros de metamorfismo termal associado. $\mathrm{Na}$ borda noroeste do Grupo ocorreu metamorfismo termal e metassomático no contato com o Complexo Granítico Cunhaporanga. Finalmente, com o soerguimento do Arco de Ponta Grossa no Cretáceo, ocorreu a intrusão de diques de diabásio que causaram metamorfismo termal de abrangência reduzida sobre as rochas metassedimentares.

\section{Metamorfismo hidrotermal na Zona de Cisalhamento Itapirapuã}

As observações de campo e análises petrográficas indicam que a talcificação do Grupo Itaiacoca foi controlada pelo fluxo de grande volume de fluido aquoso $\left(\mathrm{X}_{\mathrm{CO} 2}\right.$ inicial $\cong 0$ ) ao longo das ramificações da ZCI, possivelmente como resultado de bombeamento tectônico através de zonas sucessivas de dilatação e constrição migrantes. A talcificação hidrotermal em zonas de cisalhamento pressupõe a infiltração em grandes volumes de um fluido aquoso cuja composição foi externamente controlada, com um mínimo de tamponamento pelas reações metamórficas que promoveu. Este fluido teria sido responsável pelo transporte dos elementos acrescentados $(\mathrm{Si}, \mathrm{H})$ e removidos $(\mathrm{Ca}, \mathrm{C})$ durante a talcificação, pela hidratação e descarbonatação concomitantes, e também pelo estabelecimento das condições térmicas necessárias para que as reações metamórficas ocorressem. O bombeamento tectônico do fluido ocorreu ao longo dos planos de cisalhamento, sob regime dúctil durante a talcificação, o qual transicionou para um regime mais rúptil nas bordas e nos estágios finais do desenvolvimento destas zonas. Quase simultaneamente, nas margens das zonas de deformação dúctil, ocorreu brechação e venulação em metadolomitos não diretamente afetados pelo cisalhamento dúctil. Neste contexto, a formação do talco deve ter ocorrido pela reação:
$3 \mathrm{CaMg}\left(\mathrm{CO}_{3}\right)_{2}+4 \mathrm{SiO}_{2}(\mathrm{aq})+\mathrm{H}^{+}=\mathrm{Mg}_{3} \mathrm{Si}_{4} \mathrm{O}_{10}(\mathrm{OH})_{2}+$ $3 \mathrm{Ca}^{2+}(\mathrm{aq})+6 \mathrm{CO}_{2}$

onde a dolomita reage com o fluido aquoso portador de sílica, produzindo talco e calcita, e liberando $\mathrm{CO}_{2}$ para a fase fluida (Moine et al., 1989).

Os dados obtidos no presente trabalho indicam que o fluido mineralizante foi uma solução aquosa rica em sílica, com temperaturas máximas da ordem de 400 a $420^{\circ} \mathrm{C}$. As razões fluido-rocha estimadas foram altas, considerando-se o volume de talco formado, com tamponamento da composição do fluido pelas reações metamórficas manifestando-se apenas localmente pelo surgimento de tremolita. Os cálculos geotermométricos indicam a cristalização de calcita entre $<200$ e $420^{\circ} \mathrm{C}$, sugerindo reequilíbrio sob condições mais brandas após o pico de talcificação (Tabela 2). Os veios de quartzo associados aos talco xistos representariam aporte de sílica posterior ao pico térmico do sistema, não tendo havido condições para sua reação com a dolomita e formação de talco.

A calcita nas zonas talcificadas foi uma fase transitória, formando porfiroblastos lenticulares no talco xisto com núcleos remanescentes de metadolomito, ou franjas em veios de talcificação incipiente, mas desaparecendo nas faixas completamente talcificadas. Diversos autores (Luce et al., 1985; Fein e Walther, 1987; Shin e Lee, 2002) constataram que a fase fluida aquosa de sistemas sílico-magnesianos formadores de talco apresenta alta razão $\mathrm{Ca} / \mathrm{Mg}$, pois o $\mathrm{Mg}$ tem coeficiente de partição favorável às fases sólidas. Esta razão aumenta com o decréscimo da temperatura, visto que o Ca é preferencialmente lixiviado a temperaturas decrescentes, o que explicaria a perda preferencial de $\mathrm{Ca}$ em relação ao $\mathrm{Mg}$ durante a talcificação.

Os metadolomitos afetados de modo incipiente pelas zonas de cisalhamento contêm talco em planos de estratificação, clivagens espaçadas e redes de fraturas irregulares (Figura 3b), freqüentemente associado a núcleos de calcita ou a veios de quartzo, sugerindo a infiltração de pequenos volumes de fluido oriundo das zonas de cisalhamento. O caráter inicialmente aquoso da fase fluida é sugerido pela presença freqüente de serpentina precursora do talco nos veios submilimétricos, implicando baixa $\mathrm{X}_{\mathrm{CO} 2}$. Com o progresso da reação de talcificação, a composição do fluido pode ter sofrido modificação, apesar da alta razão fluido/rocha inferida. Localmente, os valores de $\mathrm{X}_{\mathrm{CO} 2}$ podem ter sido suficientemente altos para alcançar o ponto invariante Dol-Cc-Qtz-Tlc-Tr (ponto I, Figura 6) durante o progresso das reações metamórficas, quando tremolita se formaria tanto pela reação entre calcita, sílica e talco como diretamente entre dolomita e sílica, explicando a ocorrência localizada de tremolita nos talco xistos e nos metadolomitos incipientemente cisalhados e talcificados (Figura 2b). 


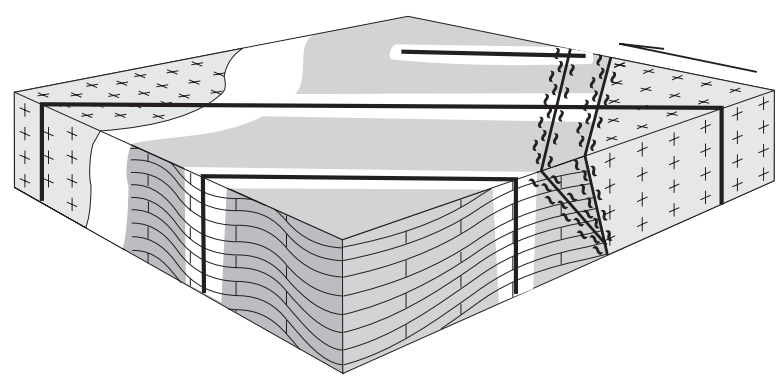

\section{Cretáceo}

Colocação dos diques de diabásio da Formação Serra Geral no Arco de Ponta Grossa e desenvolvimento de metamorfismo termal no contato com o Grupo Itaiacoca

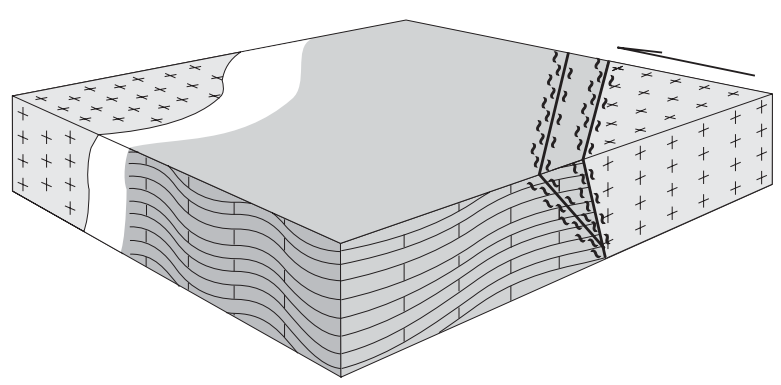

\section{Neoproterozóico}

Ciclo Brasiliano

- Colocação do Granito Cunhaporanga

- Desenvolvimento de metamorfismo

termal no contato com o Grupo

Itaiacoca

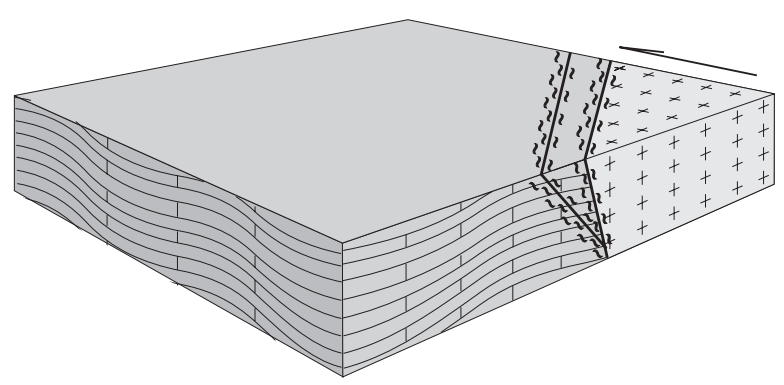

\section{Neoproterozóico}

\section{Ciclo Brasiliano}

- Metamorfismo de baixo grau e dobramento aberto do Grupo Itaiacoca

- Colocação do Granito Três Córregos

- Desenvolvimento de zonas de cisalhamento no contato do granito com o Grupo Itaiacoca e no interior do Grupo Itaiacoca

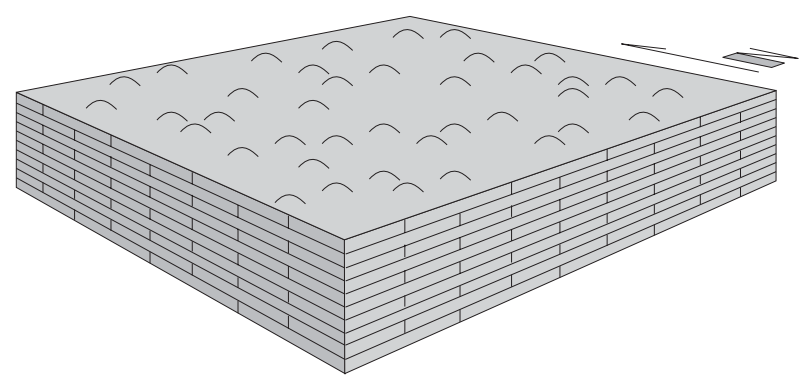

\section{Mesoproterozóico}

Sedimentação (estromatólitos)

Figura 5. Modelo simplificado da evolução geológica do Grupo Itaiacoca na região do Arco de Ponta Grossa, Paraná. 


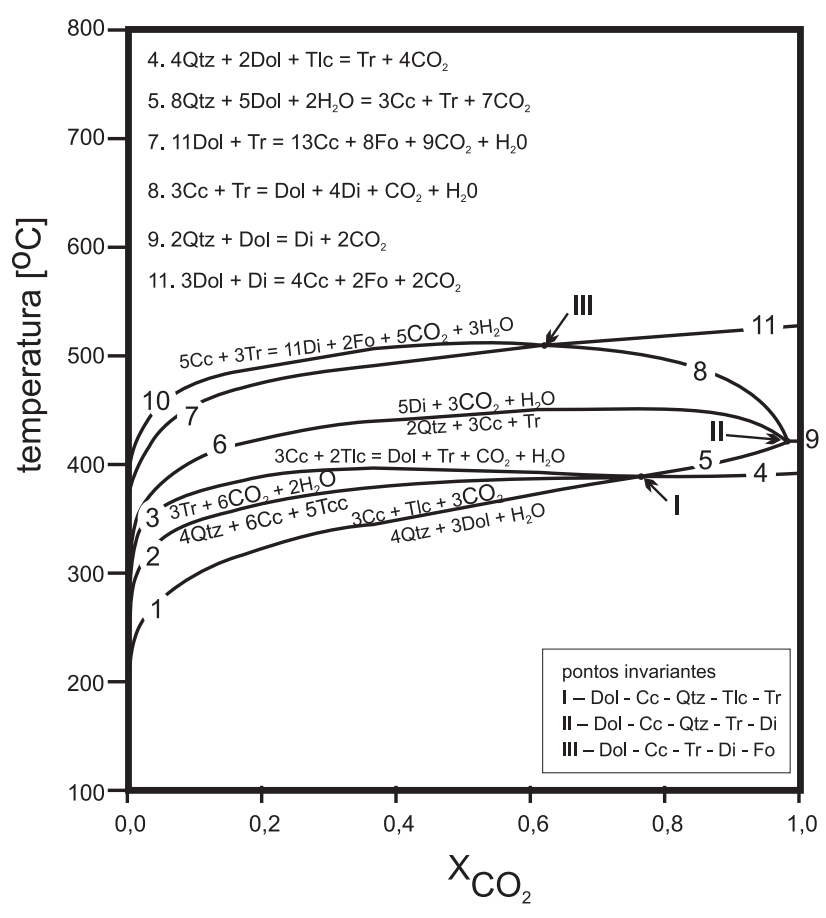

Figura 6. Diagrama de fases pseudo-binário $\mathrm{T}\left({ }^{\circ} \mathrm{C}\right) \times \mathrm{X}_{\mathrm{CO} 2}$ para o sistema dolomita - calcita - quartzo a 0,5 kb (apud Holness, 1992).

Em relação às jazidas de talco maciço fino e pulverulento, que forma bolsões irregulares com núcleos remanescentes de metadolomito, o estilo da talcificação sugere uma percolação pervasiva de soluções aquosas que teriam promovido o aporte de $\mathrm{SiO}_{2}$ e a remoção de $\mathrm{Ca}$ e $\mathrm{CO}_{2}$. A existência de relíquias da estratificação no minério de talco em continuidade com o acamamento das rochas carbonáticas sugere uma transformação estática, sem a deformação intensa associada à talcificação, como ocorre nos depósitos de talco xisto nas zonas de cisalhamento. Abundantes veios de quartzo e silicificação dos metadolomitos acompanham este processo de talcificação. A associação mineralógica é simples, incluindo talco e quartzo, além de volumes subordinados de calcita, montmorillonita e saponita, não sendo registrada a presença de tremolita. Como a porosidade intergranular de rochas carbonáticas é em geral muito baixa, o fluxo de soluções aquosas tende a ser controlado por redes de microfraturas, particularmente em rochas dolomíticas, que apresentam comportamento mecânico mais rígido (Holness e Graham, 1991; Holness e Fallick, 1997; Holness, 1997). Um modelo plausível para esta situação seria análogo ao proposto por Blount e Vassiliou (1980) para os depósitos de talco de
Winterboro, onde a formação do talco seria desvinculada do metamorfismo regional, sendo atribuída à atividade de fluidos hidrotermais ao longo de fraturas nos metadolomitos.

Os metadolomitos parcialmente talcificados, contíguos aos bolsões de talco fino pulverulento, apresentam lentes e filetes microscópicos zonados, com talco fino nas bordas e calcita granoblástica nos núcleos, de granulação e limpidez superior à da dolomita original (Figura 2e). Estes filetes e lentes ocorrem orientados segundo redes de microfraturas paralelas à ou discordantes da estratificação. Em outros casos, a talcificação incipiente manifesta-se ao longo das bordas de microfraturas submilimétricas em rede angulosa, com calcita granoblástica límpida no centro (Figura 2f). O modelo de gênese deste tipo de talco seria portanto o da infiltração de fluido silicoso nos metadolomitos ao longo de redes de

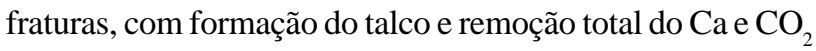
que constituiriam a calcita. Este processo foi mais eficiente onde o microfraturamento mais denso produziu um incremento na porosidade do metadolomito. Apesar da origem deste fluido não ser conhecida, parece razoável considerar a hipótese de que seja oriundo da ZCI, tendo sido injetado através das suas várias ramificações que cortam o Grupo Itaiacoca.

\section{Metamorfismo de contato do Complexo Granítico Cunhaporanga}

O metamorfismo de contato causado pelo Complexo Granítico Cunhaporanga ocorreu em níveis crustais relativamente rasos, com pressões entre $2 \mathrm{e} 4 \mathrm{Kbar}$, estimadas com base na profundidade de colocação do granito (Guimarães et al., 2000). O mineral índice mais abundante nos mármores dolomíticos é a tremolita, que ocorre em prismas longos, isolados, dispostos em planos de fratura paralelos, em agregados lenticulares e pequenos bolsões, chegando a formar agregados fibro-radiados de aspecto felpudo. Em seção delgada, é possível identificar "trilhas" de tremolita, com indivíduos prismáticos-longos isolados, isorientados, conectados pelas extremidades por uma rede de fraturas muito finas, praticamente imperceptíveis. Em muitos casos, os prismas de tremolita exibem "franjas" de calcita (Figura 2d), sugerindo a reação:

$5 \mathrm{CaMg}\left(\mathrm{CO}_{3}\right)_{2}+\mathrm{H}_{2} \mathrm{O}+8 \mathrm{SiO}_{2}(\mathrm{aq})=\mathrm{Ca}_{2} \mathrm{Mg}_{5} \mathrm{Si}_{8} \mathrm{O}_{22}(\mathrm{OH})_{2}+$ $3 \mathrm{CaCO}_{3}+7 \mathrm{CO}_{2}$

Nestas rochas, a formação de talco é incipiente e sobreposta à de tremolita, sugerindo reequilíbrio tardio durante o estágio evanescente do metamorfismo hidrotermal, já dentro do campo de estabilidade do talco. Diopsídio e forsterita ocorrem no núcleo de alguns bolsões zonados, alinhados dentro do acamamento complexamente deformado (Figura 3d), possivelmente pela evolução do fluido aquoso 
percolante para composições mais carbônicas. A composição do fluido aquoso, fornecido em volume relativamente restrito pela cristalização do complexo granítico, teria sido eficientemente tamponada pelas reações metamórficas ocorridas nas rochas dolomíticas, deslocando o equilíbrio em direção à curva de equilíbrio entre dolomita-quartzo (sílica)-tremolita-calcita e ao ponto invariante Dol-Cc-Qtz-Tr-Di (ponto II, diagrama $\mathrm{T}-\mathrm{X}_{\mathrm{CO} 2}$, Figura 6), permitindo a blastese de tremolita diretamente a partir do metadolomito percolado por um fluido reativo portador de sílica, e eventualmente até a blastese de diopsídio mesmo sem um aumento significativo de temperatura. Nos casos em que o fluido metamórfico está presente em proporção reduzida e com tempo de residência relativamente longo, obrigatoriamente ocorre o tamponamento da fase fluida no metamorfismo das rochas carbonáticas (e.g. Greenwood, 1975). As temperaturas mais altas, de $530^{\circ} \mathrm{C}$ ( $\mathrm{X}_{\mathrm{Mg}}$ calcita) foram registradas em mármores dolomíticos com tremolita nesta zona de contato. Pela configuração das curvas de equilíbrio do diagrama da Figura 6, esta temperatura máxima obtida seria compatível com os campos de estabilidade de forsterita, acompanhada ou não de diopsídio, sendo a associação tremolita-calcita metaestável nestas condições. A formação da forsterita deve ter ocorrido em condições de pico metamórfico, e não necessariamente em presença de fase fluida com alta $\mathrm{X}_{\mathrm{CO} 2}$. As relações texturais entre os diversos minerais-índices nos bolsões são, por enquanto, inconclusivas para a elucidação do metamorfismo progressivo dos metadolomitos na zona de contato com o Granito Cunhaporanga. Dados adicionais de inclusões fluidas e de composição mineral serão necessários para avaliar, mais rigorosamente, a sequiência de reações que ocorreu durante este episódio metamórfico. Vale mencionar as conclusões de Holness (1992) para uma situação similar na ilha de Skye (Escócia), onde a fase fluida parece ter se manifestado em pulsos discretos, de composição variável, gerando assembléias de minerais metamórficos que não alcançaram equilíbrio termodinâmico interno.

O metamorfismo de contato e hidrotermal associado nas vizinhanças do Complexo Granítico Cunhaporanga não produziu concentrações significativas de talco. $\mathrm{O}$ talco neste caso é de origem retrometamórfica, sobrepondo-se às paragêneses de mais alta temperatura e ocorre em quantidade ínfima.

\section{Metamorfismo de contato dos diques de diabásio}

O metamorfismo termal no contato com os diques de diabásio recristalizou localmente os metadolomitos, transformando-os em mármores dolomíticos e calcíticos, mas sem levar à formação de talco. Os diques truncam as faixas mineralizadas em talco das zonas de cisalhamento. Nos metadolomitos afetados por este tipo de metamorfismo se desenvolveram venulações de pequeno porte contendo brucita e serpentina, e localmente forsterita. Nas proximidades de diques possantes ou em megaxenólitos de metadolomitos nos diques, houve a formação de mármores brancos dolomíticos e calcíticos, explorados para uso cerâmico (Reis Neto et al., 2004). Quando estes mármores se apresentam talcosos, trata-se mais provavelmente de metadolomitos previamente talcificados submetidos ao metamorfismo de contato pelos diques, e não de talco formado por conseqüência deste metamorfismo de contato. Nas demais seqüências metassedimentares portadoras de dolomita da Faixa Ribeira (Formações Capiru, Votuverava e Água Clara), cortadas pelos diques de diabásio do Arco de Ponta Grossa, não há registro de talcificação significativa.

\section{CONCLUSÕES}

Os metadolomitos do Grupo Itaiacoca foram submetidos a quatro episódios metamórficos, na seguinte ordem:

1. metamorfismo regional de baixo grau, facies xisto verde - zona da clorita;

2. metamorfismo de contato e hidrotermal a noroeste, ao longo da borda do Complexo Granítico Cunhaporanga;

3. metamorfismo dinâmico acompanhado de intensa atividade hidrotermal ao longo de ramificações da Zona de Cisalhamento Itapirapuã (ZCI);

4. metamorfismo termal de abrangência localizada causado pelos diques de diabásio mesozóicos.

Destes episódios, apenas o metamorfismo hidrotermal associado à ZCI gerou depósitos de talco xistos. Quantidades subordinadas de talco retrometamórfico formaram-se na auréola de metamorfismo de contato com os granitos do Complexo Granítico Cunhaporanga. Não se observou talco associado aos metadolomitos afetados por metamorfismo regional ou pela auréola de metamorfismo de contato dos diques.

A talcificação ocorreu em quatro padrões distintos nos metadolomitos:

a. talco xisto nas zonas de cisalhamento anastomosadas, com lentes residuais de dolomito e calcita;

b. filmes e veios de talcificação incipiente em metadolomitos, acompanhando descontinuidades estruturais;

c. bolsões irregulares de talco maciço fino, pulverulento, de aspecto argiloso quando úmido, que substitui o metadolomito estratificado de maneira estática;

d. talco retrometamórfico associado a lentes de olivina, diopsídio, tremolita, calcita e quartzo nos mármores dolomíticos da auréola de contato do Complexo Granítico Cunhaporanga. 
Destas, apenas os tipos (a) e (c) constituem jazidas. Os metadolomitos incipientemente talcificados podem constituir minérios de interesse para fins cerâmicos.

Os dados obtidos permitiram estimar as características do fluido mineralizante apenas no caso dos talco xistos (tipo a) e nos bolsões de talco maciço pulverulento (tipo c). Este fluido aquoso era rico em sílica, com temperatura inicial máxima em torno de $400-420^{\circ} \mathrm{C}$, baixa $\mathrm{X}_{\mathrm{CO} 2}$, e percolou o metadolomito através de descontinuidades estruturais por bombeamento tectônico nas zonas de cisalhamento e suas ramificações. As observações sugerem que estes mesmos fluidos possam ter causado a talcificação incipiente ao longo das descontinuidades estruturais dos metadolomitos não diretamente afetados pela zona de cisalhamento, e serem responsáveis pela formação dos bolsões de talco fino, maciço, pulverulento, porém com indicações de temperaturas mais baixas, até inferiores a $200^{\circ} \mathrm{C}$.

Os minérios de talco explorados no Grupo Itaiacoca apresentam-se contaminados em proporção significativa por quartzo e calcita, provenientes em sua maior parte da reação metamórfica formadora do talco e dos veios de quartzo tardios. Nos talco xistos da região de Itaiacoca há ocorrência ocasional de tremolita asbestiforme. Este mineral tem ocorrência sistemática nos mármores dolomíticos da zona de contato com o Complexo Granítico Cunhaporanga, explorados para fins cerâmicos. Asbesto de serpentina tem ocorrência subordinada nos talco xistos e metadolomitos incipientemente talcificados, bem como nos mármores dolomíticos e calcíticos das zonas de contato dos diques de diabásio.

\section{AGRADECIMENTOS}

Agradecemos ao suporte técnico de Marcos Mansueto (microssonda eletrônica), Sandra Andrade e Paulo Mori (química de rocha total), e aos estudantes do curso de Geologia do IGc-USP Fernando Machado Alves, Murilo César Vieira Perrella, Conrado Eugenius Borges Picolo e Bruno Boito Turra, em diversas etapas deste trabalho. Contamos com o apoio das empresas de mineração Costalco/ Marc Minerais Industriais, Mineração São Judas, Mineração Irapuru, Colorminas, Transcomin, Calponta Calcário, Calfranco, Calsanto, Itajara Minérios e Mineração Lagoa Bonita, que nos permitiram acesso às lavras. Este trabalho foi financiado pela FAPESP (projeto 00/03115-3) e contou com apoio do Projeto Temático 97/00640-5.

\section{REFERÊNCIAS BIBLIOGRÁFICAS}

ALMEIDA, F. F. M. de. Novas ocorrências de fósseis no pré-cambriano brasileiro. Anais da Academia Brasileira de Ciências, v. 28, p. 44-45, 1956.
ALMEIDA, F. F. M. Relações tectônicas das rochas alcalinas mesozóicas da região meridional da plataforma sul-americana. Revista Brasileira de Geociências, v. 13, n. 3, p. 139-158, 1983.

ANDERSON, D.L.; MOGK, D. W.; CHILDS, J.F. Petrogenesis and timing of talc formation in the Ruby Range, Southwestern Montana. Economic Geology, v. 85, p. 585-600, 1990.

ANOVITZ, L. M.; ESSENE, E. J. Phase equilibria in the system $\mathrm{CaCO}_{3}-\mathrm{MgCO}_{3}-\mathrm{FeCO}_{3}$. Journal of Petrology, v. 28, p. 389-414, 1987.

ARAÚJO, J. C. K.; GODOY L. C.; SOUZAP. E. C.; DIAS R. B. Caracterização, prospecção e avaliação de jazidas de talco da Faixa Itaiacoca no Estado do Paraná. In: SIMPÓSIO SULBRASILEIRO DE GEOLOGIA, 3., 1987. Curitiba. Anais... Curitiba: SBG, 1987. v. 2, p. 633-643.

BARbOSA, O. Pesquisa da jazida de talco de Moura, Distrito de Itaiacoca, Município de Ponta Grossa, Estado do Paraná. (Decreto n 13.330, de 13/09/43), 1943.

BIGARELLA, J. J. Ocorrência de dolomito no município de Cêrro Azul, Paraná. Mineração e Metalurgia, v. 11, n. 66, p. 323-326, 1947.

BLOUNT, A. M.; VASSILIOU, A. H. The mineralogy and origin of the talc deposits near Winterboro, Alabama. Economic Geology, v. 75, p. 107-116, 1980.

BOWEN, N. L. Progressive metamorphism of siliceous limestone and dolomite. Journal of Geology, v. 48, p. 225-274, 1940.

COOK, S. J.; BOWMAN, J. R. Contact metamorphism surrounding the Alta stock: thermal constraints and evidence of advective heat transport from calcite + dolomite thermometry. American Mineralogist, v. 79, p. 513-525, 1994.

CPRM - Companhia de Pesquisa de Recursos Minerais. Projeto Leste do Paraná: Folha Piraí do Sul, escala 1:100.000. São Paulo: DNPM; CPRM; BADEP, 1977. v. 1. 119 p. (Relatório final).

DNPM - Departamento Nacional de Produção Mineral. Talco e pirofilita. Sumário Mineral 2003. Disponível em: <www.dnpm.gov.br>. Acesso em: 26 jan 2006.

DNPM/MINEROPAR - Departamento Nacional de Produção Mineral-Minerais do Paraná S.A. Avaliação Metalogenética do Distrito Mineiro do Talco no Estado do Paraná. Curitiba. 
Autores: Ribas, S. M.; David, C. A. S.; Brandão, W.; Valaski, Z. de F. (Relatório final - textos e anexos).

EGGERT, R. G.; KERRICK, D. M. Metamorphic equilibria in the siliceous dolomite system: 6 kbar experimental data and geologic implications. Geochimica et Cosmochimica Acta, v. 45, p. 1039-1049, 1981.

EL-SHARKAWY, M. F. Talc mineralization of ultramafic affinity in the Eastern Desert of Egypt. Mineralium Deposita, v. 35, p. 346-363, 2000.

EVANS, B. W.; GUGGENHEIM, S. Talc, pyrophyllite and related minerals. Reviews in Mineralogy, v. 19, p. 225-294, 1988.

FASSBINDER, E., A Unidade Água Clara no contexto do Grupo Açunguí: um modelo transpressivo de colisão oblíqua no Neoproterozóico paranaense. 1996. 207 f. Tese (Doutorado) - Instituto de Geociências, Universidade de São Paulo, São Paulo, 1996.

FEIN, J. B.; WALTHER, J. V. Calcite solubility in supercritical $\mathrm{CO}_{2}-\mathrm{H}_{2} \mathrm{O}$ fluids. Geochimica et Cosmochimica Acta, v. 51, p. $1665-1673,1987$.

FUCK, R. A. Geologia da Folha de Abapã. Boletim da Universidade Federal do Paraná, v. 25, p. 33, 1967.

GONDIM, A. C.; LOYOLA, L. C. Ponta Grossa and Castro zones in Paraná talc district, Brazil: ore properties and mineral industry. Boletim Paranaense de Geociências, v. 50, p. 9-14, 2002.

GORDON, T. M.; GREENWOOD, H. J. The reaction: dolomite + quartz + water $=$ talc + calcite + carbon dioxide. American Journal of Science, v. 268, p. 225-242, 1970.

GREENWOOD, H. J. Buffering of pore fluids by metamorphic reactions. American Journal Science, v. 275, p. 573-593, 1975.

GUIMARÃES, G. B. As rochas granitóides do Complexo Granítico Cunhaporanga: aspectos geológicos, geofísicos, geoquímicos e mineralógicos. 2000. 230 f. Tese (Doutorado) - Instituto de Geociências, Universidade de São Paulo, São Paulo, 2000.

GUIMARÃES, G. B.; ULBRICH, H. H. G. J.; JANASI, V. A. Geothermobarometry of granitoid rocks: a case study from the Neoproterozoic Cunhaporanga Granitic Complex, southern Brazil. In: INTERNATIONAL GEOLOGICAL CONGRESS, 31., 2000, Rio de Janeiro. Anais... Rio de Janeiro: [s.n.], 2000.
HASUI, Y.; CARNEIRO, C. D. R.; COIMBRA, A. M. The Ribeira folded belt. Revista Brasileira de Geociências., v. 5, n. 4, p. 257-266, 1975.

HECHT, L.; FREIBERGER, R.; GILG, H. A.; GRUNDMANN, G.; KOSTITSYN, Y. A. Rare earth element and isotope $(\mathrm{C}, \mathrm{O}, \mathrm{Sr})$ characteristics of hydrothermal carbonates: genetic implications for dolomite-hosted talc mineralization at Göpfersgrün (Fichtelberg, Germany). Chemical Geology, v. 155 , p. 115-130, 1999.

HOLNESS, M. B. Metamorphism and fluid infiltration of the calc-silicate aureole of the Beinn an Dubhaich granite, Skye. Journal of Petrology, v. 33, p. 1261-1293, 1992.

HOLNESS, M. B. Fluid flow paths and mechanisms of fluid infiltration in carbonates during contact metamorphism: the Beinn an Dubhaich aureole, Skye. Journal of Metamorphic Geology, v. 15, p. 59-70, 1997.

HOLNESS, M. B.; FALLICK, A. E. Palaeohydrology of the calcsilicate aureole of the Beinn an Dubhaich granite, Skye, Scotland: a stable isotopic study. Journal of Metammorphic Geology, v. 5, p. 71-83, 1997.

HOLNESS, M. B.; GRAHAM, C. M. Equilibrium dihedral angles in the system $\mathrm{H}_{2} \mathrm{O}-\mathrm{CO}_{2}-\mathrm{NaCl}$ - calcite, and implications for fluid flow during metamorphism. Contribution to Mineralogy and Petrology, v. 108, p. 368-383, 1991.

HUTCHISON, C. S. Laboratory Handbook of Petrographic Techniques. New York: Wiley Interscience, 1974. 527 p.

INSTITUTODE PESQUISAS TECNOLÓGICAS (São Paulo). Geologia das Folhas Barra do Chapéu (SG-22-X-B-I-4) e Araçaíba (SG-22-X-B-II-3), Estados de São Paulo e Paraná. São Paulo: IPT, 1985. (Relatório n. 22.150).

LETARGO, C. M.; LAMB, W. M.; PARK, J. S. Comparison of calcite + dolomite thermometry and carbonate + silica equilibria: constraints on the conditions of metamorphism of the Llano uplift, central Texas, U.S.A. American Mineralogist, v. 80, p. 131-143, 1995.

LIMA, R. E. Evolução geológica dos depósitos de talco da região de Itaiacoca e Abapã - Paraná. In: CONGRESSO BRASILEIRO DE GEOLOGIA, 37., 1992, São Paulo. Anais... São Paulo: SBG, 1992. v. 1, p. 265-266.

LIMA, R. E. Evolução geológica e controles dos depósitos de talco da região de Itaiacoca, Abapã, PR. 1993a. 139 f. 
Dissertação (Mestrado) - Instituto de Geociências, Universidade de Brasília, Brasília, 1993.

LIMA, R. E. Geologia da Faixa Itaiacoca / PR: estratigrafia, litologias, depósitos de talco e intrusivas associadas. In: SIMPÓSIO SUL BRASILEIRO DE GEOLOGIA, 5., 1993, Curitiba. Anais... Curitiba: SBG, 1993b. v. 2, p. 30-35.

LIMA, R. E. Geologia das jazidas de talco do Paraná. In: ENCONTRODEMINERADORES ECONSUMIDORES, 5., 1997, Ponta Grossa. Anais...Ponta Grossa: Associação Brasileira de Cerâmica; SENAI-PR, 1997, p. 8-11.

LIMA, R. E.; DARDENNE, M. A. Geologia e controle da Mina Grande da Costalco - Itaiacoca (PR). In: SIMPÓSIO SULBRASILEIRODEGEOLOGIA, 3., 1987, Curitiba. Anais... Curitiba: SBG, 1987. v. 2, p. 623-632.

LUCE, R. W.; CYGAN, G. L.; HEMLEY, J. J.; D'ANGELO, W. $\mathrm{M}$. Some mineral stability relations in the system $\mathrm{CaO}-\mathrm{MgO}-$ $\mathrm{SiO}_{2}-\mathrm{H}_{2} \mathrm{O}-\mathrm{HCl}$. Geochimica et Cosmochimica Acta, v. 49, p. 525-538, 1985.

MARINI, O.; TREIN, E.; FUCK, R. A. O Grupo Açunguí no Estado do Paraná. in: Bigarella, J.J., Salamuni, R., Pinto, V.M. (eds.) Geologia do Pré-Devoniano e instrusivas subseqüentes da porção oriental do Estado do Paraná. Boletim Paranaense de Geociências, v. 23-25, p. 43-103, 1967.

MOINE, B.; FORTUNE, J. P.; MOREAU, P.; VIGUIER, F. Comparative mineralogy, geochemistry, and conditions of formation of two metasomatic talc and chlorite deposits: Trimouns (Pyrenees, France) and Rabenwald (Eastern Alps, Austria). Economic Geology, v. 84, p. 1398-1416, 1989.

PRAZERES FILHO, H. J. Litoquímica, geocronologia ( $U$ $\mathrm{Pb}$ e e geologia isotópica dos complexos graníticos Cunhaporanga e Três Córregos, Estado do Paraná. 2000. 180f. Dissertação (Mestrado) - Instituto de Geociências, Universidade de São Paulo, São Paulo, 2000.

PRAZERES FILHO, H. J.; GUIMARÃES, G. B.; BASEI, M. A. S.; SIGA JR., O.; REIS NETO, J. M.; CAMPANHA, G. A. C.; SALLUN FILHO, W. Mapa geológico 1:50.000 da porção centro-sul da Faixa Itaiacoca-PR. In: CONGRESSO BRASILEIRO DE GEOLOGIA, 40., 1998, Belo Horizonte. Anais... Belo Horizonte: SBG, 1998. p. 36.

PRAZERES FILHO, H. J.; HARARA, O. M.; BASEI, M. A. S.; PASSARELLI, C. R.; SIGA JR., O. Litoquímica, geocronologia $\mathrm{U}-\mathrm{Pb}$ e geologia isotópica $(\mathrm{Sr}-\mathrm{Nd}-\mathrm{Pb})$ das rochas graníticas dos Batólitos Cunhaporanga e Três Córregos na porção sul do Cinturão Ribeira, Estado do Paraná. Geologia-USP. Série Científica, v. 3, p. 51-70, 2003.

PROCHASKA, W. Geochemistry and genesis of Austrian talc deposits. Applied Geochemistry, v. 4, p. 511-525, 1989.

PROCHASKA, W.; MOGESSIE, A.; RAITH, J. G. Formation of the talc deposit of Kibanda (Rwanda) and its relation to the regional metamorphic evolution. Journal of African Earth Sciences, v. 14, p. 499-509, 1992.

PUHAN, D. Metamorphic evolution of the assemblage tremolite + talc + calcite + dolomite + quartz within a sample of siliceous dolomite from the southern Damara Orogen (Namibia). Contributions to Mineralogy and Petrology, v. 120, p. 180-185, 1995.

REIS NETO, J. M. Faixa Itaiacoca: registro de uma colisão entre dois blocos continentais no Neoproterozóico. 1994. 235 f. Tese (Doutorado) - Instituto de Geociências, Universidade de São Paulo, São Paulo, 1994.

REIS NETO, J. M.; REBELO, A. M. A.; BASEI, M. A. S. JuraCretaceous hydrothermalism as genesis of mineralization in dolomitic marbles of Itaiacoca Belt, Brazil. In: INTERNATIONAL CONGRESS ON APPLIED MINERALOGY, 8., 2004, Águas de Lindóia. Proceedings... Águas de Lindóia: IMA, 2004. v. 1, p. 733-736.

RENNE, P. R.; DECKART, K.; ERNESTO, M.; FÉRAUD, G; PICCIRILLO, E. M. Age of the Ponta Grossa dike swarm (Brazil), and implications to Paranánext term flood volcanism. Earth Planetary Science. Letters, v. 144, n. 1-2, p. 199-211, 1996.

RIBAS, S. M.; GUIMARÃES, S. B.; ADAM, E. R. Avaliação Metalogenética do Distrito Mineiro do Talco no Estado do Paraná. Curitiba: DNPM; MINEROPAR, 1999. (Relatório Final. Texto e anexos).

RICE J. M. Progressive metamorphism of impure dolomitic limestone in the Marysville aureole, Montana. American Journal of Science, v. 277, p. 1-24, 1977.

SCHANDL, E. S.; SHARARA, N. A.; GORTON, M. P. The origin of the Atshan talc deposit in the Hamata area, eastern Desert, Egypt: a geochemical and mineralogical study. Canadian Mineralogist, v. 37, p. 1211-1227, 1999.

SHIN, D.; LEE, I. Carbonate-hosted talc deposits in the contact aureole of an igneous intrusion (Hwanggangri mineralized zone, South Korea): geochemistry, phase 
relationships, and stable isotope studies. Ore Geology Reviews, v. 22, p. 17-39, 2002.

SIGA JR., O.; BASEI, M. A. S.; SATO, K.; PRAZERES FILHO, H. J.; CURY, L. F.; WEBER, W.; PASSARELLI, C. R.; HARARA, O. M.; REIS NETO, J. M. U-Pb (zircon) ages of metavolcanic rocks from the Itaiacoca Group: tectonic implications. Geologia-USP. Série Científica, v. 3, p. 39-49, 2003.

SKIPPEN, G. An experimental model for low pressure metamorphism of siliceous dolomitic marble. American Journal of Science, v. 274, p. 487-509, 1974.

SKIPPEN, G.; TROMMSDORFF, V. The influence of $\mathrm{NaCl}$ and $\mathrm{KCl}$ on phase relations in metamorphosed carbonate rocks. American Journal of Science, v. 286, p. 81-104, 1986.

SLAUGHTER, J.; KERRICK, D. M.; WALL, V. J. Experimental and thermodynamic study of equilibria in the system $\mathrm{CaO}-$ $\mathrm{MgO}-\mathrm{SiO}_{2}-\mathrm{H}_{2} \mathrm{O}-\mathrm{CO}_{2}$. American Journal of Science, v. 275, p. 143-162, 1975.

SOARES, P .C. 1987. Sequiências tecto-sedimentares e tectônica deformadora no centro-oeste do Escudo Paranaense. In: SIMPÓSIO SUL BRASILEIRO DE GEOLOGIA, 3., 1987, Curitiba. Anais... Curitiba: SBG, 1987. v. 2, p. 743-771.

SOARES, P.C.; STEVANATTO, R.; CAMARGO, C.R. 1987. Geologia do noroeste da Faixa Itaiacoca - Paraná. In: SIMPÓSIO SUL BRASILEIRO DE GEOLOGIA, 3., 1987, Curitiba. Anais... Curitiba: SBG, 1987. v. 1, p. 245-262.

SOBANSKI, A.; GIUSTI, D. A.; CHODUR, N. L. As jazidas de talco de Abapã, município de Castro (PR). In: In: CONGRESSO BRASILEIRO DE GEOLOGIA, 33., 1984, Rio de Janeiro. Anais... Rio de Janeiro: SBG, 1984. v. 8, p. 3799-3808.

SOUZA, A. Mapa Geológico na escala 1:50.000 e esboço da evolução tectônica e sedimentar do Grupo Itaiacoca, nas folhas Barra do Chapéu e Ouro Verde - SP/PR. 1990. 200 f. Dissertação (Mestrado) - Instituto de Geociências, Universidade de São Paulo, São Paulo, 1990.

SPEAR, F., Metamorphic phase equilibria and pressuretemperature-time paths. Washington: Mineralogical Society of America, [c1993]. (Monograph / Mineralogical Society of America).

SZABÓ, G. A. J.; ANDRADE, F. R. D.; GUIMARÃES, G. B.; MOYA, F. A.; CARVALHO, F. M. S. Genesis of talc deposits and the metamorphic history of the Itaiacoca Group metadolomites, southern Brazil. In: INTERNATIONAL CONGRESS ON APPLIED MINERALOGY, 8., 2004, Águas de Lindóia. Proceedings... Águas de Lindóia: IMA, 2004. v. 1, p. 759-761.

TILLEY, C. E. Earlier stages in the metamorphism of siliceous dolomite. Mineralical Magazine, v. 85, p. 213-216, 1948.

TORNOS, F.; SPIRO, B. F. The geology and isotope geochemistry of the talc deposits of Puebla de Lillo (Cantabrian Zone, Northern Spain). Economic Geology, v. 95, p. 1277-1296, 2000.

WEBER, W.; SIGA JR., O.; SATO, K.; REIS NETO, J. M.; BASEI, M. A. S.; NUTMAN, A. P. A Formação Água Clara na região de Araçaiba - SP: registro U-Pb de uma bacia mesoproterozóica. Geologia USP. Série Científica, v. 4, p. 101-110, 2004. 